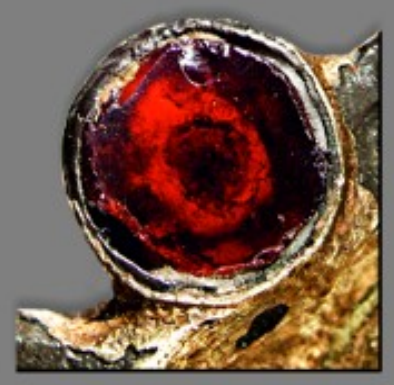

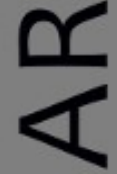

$\sim$

ш
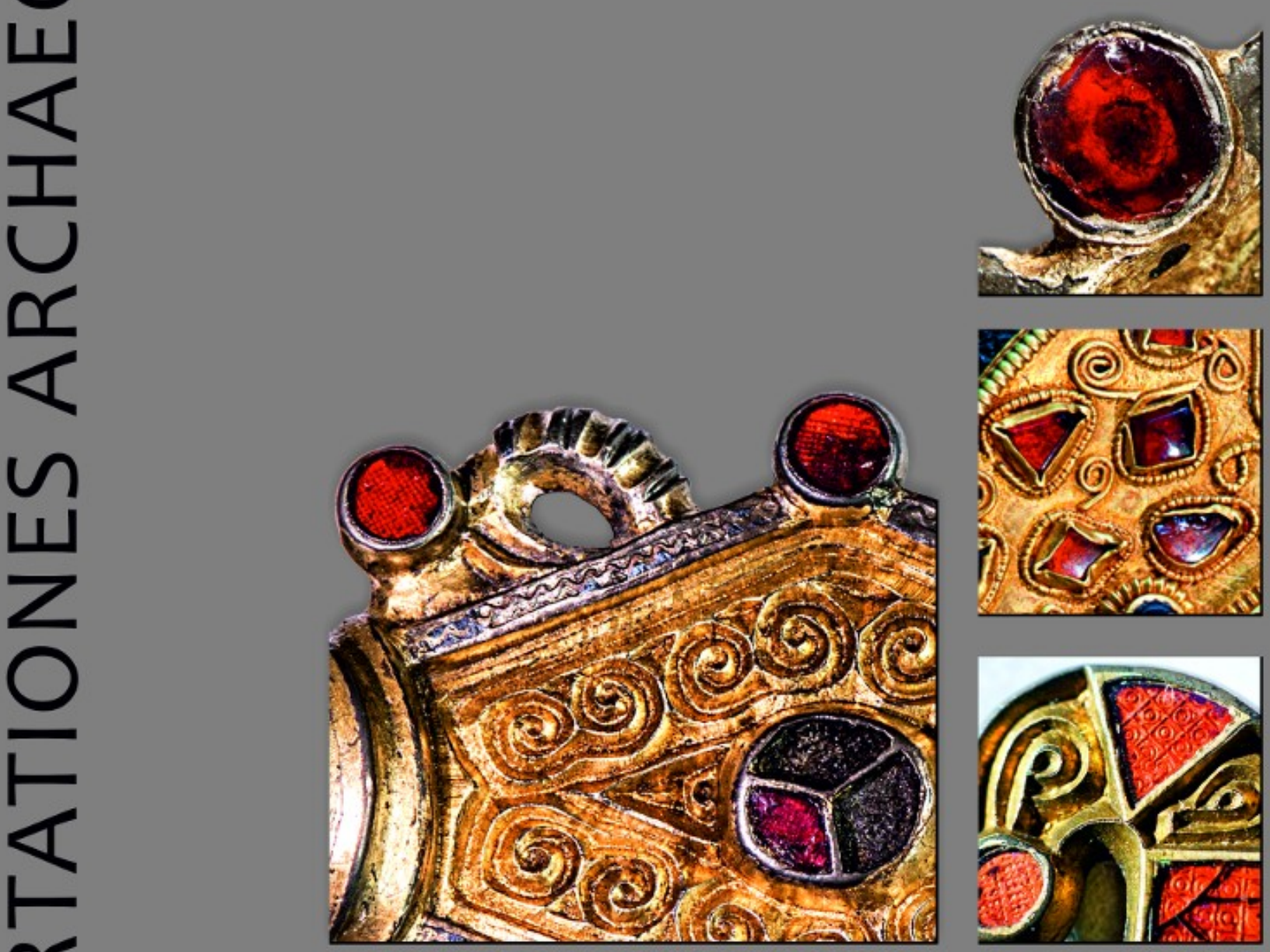

E

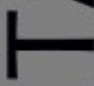

œ

山

n

ก

$\overline{0}$
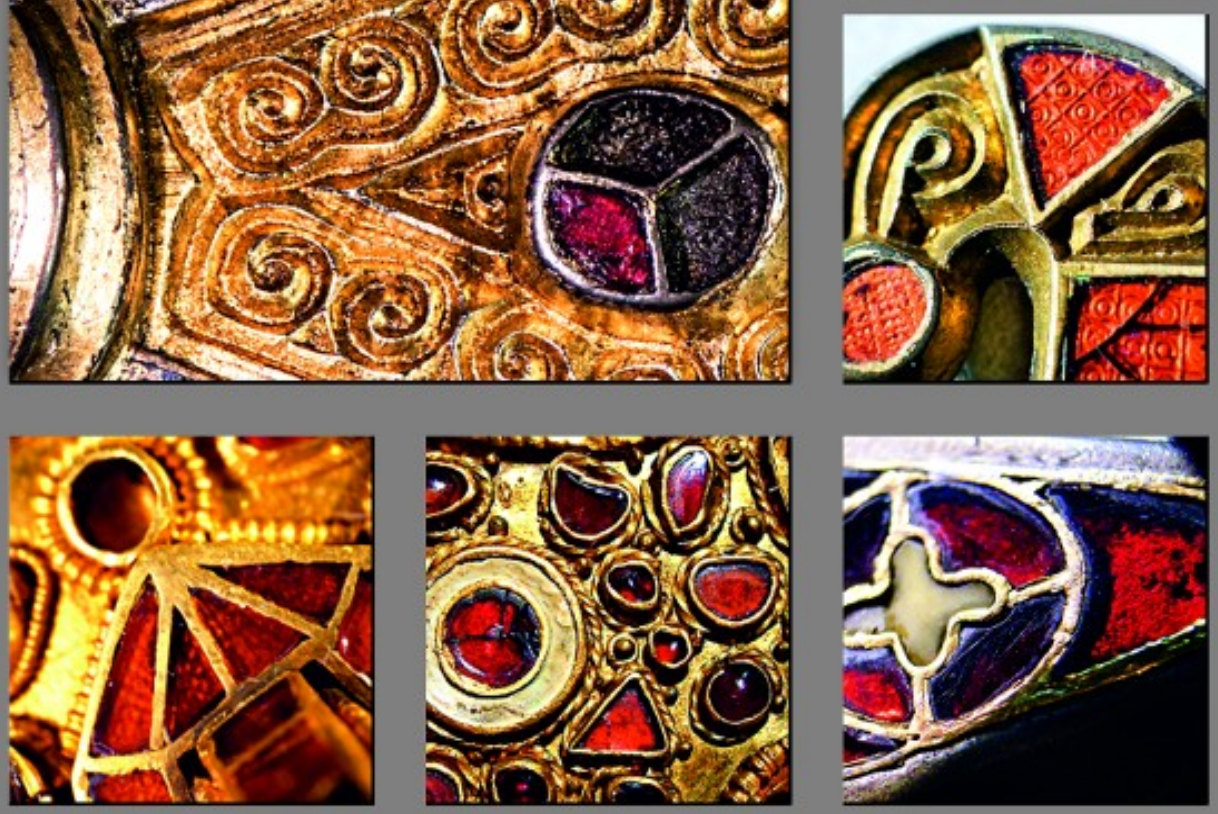

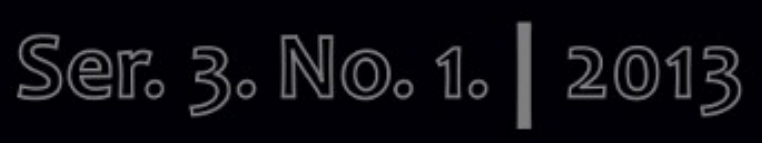




\section{Dissertationes Archaeologicae ex Instituto Archaeologico}

Universitatis de Rolando Eötvös nominatae Ser. 3. No. 1.

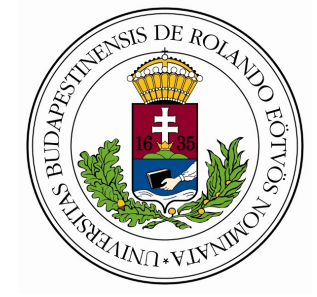

Budapest 2013 
Dissertationes Archaeologicae ex Instituto Archaeologico

Universitatis de Rolando Eötvös nominatae

Ser. 3. No. 1.

Editor-in-chief:

DÁvid BARTUS

Editorial board:

LÁSZLÓ BARTOSIEWICZ

LÁSZLÓ BORHY

ISTVÁN FELD

GÁBOR KALLA

PÁL RACZKY

Miklós SzABÓ

TIVADAR VIDA

Technical editors:

DÁvid BARTuS

GÁBOR VÁCZI

ANDRÁs BöDŐcs

Proofreading:

Zsófia KondÉ

SzILvia SzÖLlősI

Available online at http://dissarch.elte.hu

Contact: dissarch@btk.elte.hu

\section{$\underline{\text { PKP }}$ \\ PUBLIC \\ KNOWLEDGE \\ PROJECT}

(C) Eötvös Loránd University, Institute of Archaeological Sciences

Budapest 2013 


\section{Contents}

\section{Articles}

Melinda TORBÁGYI - István VIDA

The coin hoard of Abasár

Anikó BózsA

21

Roman mirrors from a private collection in the Hungarian National Museum

Lajos JuHÁsz

45

The Biesheim cameo - a reinterpretation

\section{Methods}

Péter CsIPpÁN

$A z$ állatcsont, mint információhordozó leletanyag

Kata DÉvAI

Terminológiai alapfogalmak régészeti korú üvegtárgyak elemzéséhez

Lőrinc TimáR - Zoltán Czajlik - Sándor Puszta - Balázs Holl

$3 D$ reconstructions using GPR data at the Mont Beuvray

\section{FIELD REPORTS}

Zsolt MESTER

Excavation at a new Upper Palaeolithic site of the Eger region (Northern Hungary)

László BORHY - Dávid BARTus - Emese SzÁmadó

Short report on the excavations at Brigetio (Szőny-Vásártér) in 2013

Dénes HulLÁm - Zsófia RÁcz

Report on the participation of the Eötvös Loránd University at the Wielbark Archaeological Field School in Malbork-Wielbark, Poland

Gábor VÁczi - Dávid BARTus

Short report on the excavations at the site Makó - Igási Ugar

Maxim MoRdovin

Short report on the excavations in 2013 of the Department of Hungarian Medieval and Early Modern Archaeology (Eötvös Loránd University, Budapest)

\section{THESIS ABSTRACTS}

Kitti KÖHLER

Biological reconstruction of the Late Neolithic Lengyel Culture 
Cultural connections and interactions of Eastern Transdanubia during the Urnfield period

Orsolya LÁNG

Urban problems in the civil town of Aquincum: the so-called „northern band”

Nikoletta SEY

Questions of bronze workshops in Roman Pannonia

Kata DÉvaI

Glass vessels from Late Roman times found in graves in the Hungarian part of Pannonia

Eszter HORvÁTH

Gemstone and glass inlaid fine metalwork from the Carpathian Basin:

the Hunnic and Early Merovingian Periods

Gergely SzEnTHE

Vegetal ornaments in the Late Avar decorative art

Péter LANGó

Relations between the Carpathian Basin and South East Europe during the 10th century.

The evidence of the minor objects

Ciprián HoRvÁTH

The Cemeteries and Grave Finds of Györ and Moson Counties from the Time

of the Hungarian Conquest and the Early Árpádian Age

András Sófalvi

The border- and self-defence of Szeklers from the Medieval Age till the Age of Principality.

Castles and other defence objects in the settlement history of Udvarhelyszék 


\title{
Terminológiai alapfogalmak régészeti korú üvegtárgyak elemzéséhez
}

KATA DÉVAI

MTA-ELTE Research Group for Interdisciplinary Archaeology

Eötvös Loránd University

kata.devai@gmail.com

\begin{abstract}
This study aims at creating a Hungarian glossary of terms, which the Hungarian archaeological publications are short of. To describe the glass objects accurately an all-embracing terminology must be used. Forms of the objects do not provide enough information to their analysis, hence their process of manufacture, the parts of the vessels, the decoration methods, the analysis of the colours and qualities are essential features. The current names of the process, tools and equipment used in modern glass production should be compared with the ones used in ancient times and terms which reflect the ancient methods and devices should be preferred. As some of the ancient manufacture techniques did not have Hungarian name, foreign expressions were applied. In the first part of the article the most frequent equipment and devices are listed. In the second part the principal constituents and the additives of glassmaking are discussed. The third part is an outline of the main glassmaking process. These parts also contribute to the depiction of the objects. The fourth part includes decorating techniques, the fith and the sixth sections deal with the variety of colours and the transparency of objects. The last part represents the characteristic features of glass vessels including the methods of finishing the rims, bases and handles, which were formed at different temperatures.
\end{abstract}

Az üveg alapanyagának amorf volta, a hőmérséklet változásával folyamatosan alakuló kémiai, fizikai tulajdonságai, a hozzáadott segédanyagok sokszínűsége indokolttá teszi egy pontos terminológia kidolgozását, amely megkönnyítheti az üvegtárgyak szakszerű, pontos leírását. Ehhez nélkülözhetetlen annak a néhány szerszámnak és eszköznek az egységes megnevezése, amelyet az üveggyártáskor használtak, ugyanis ezek némelyikének nyoma megfigyelhető a kész tárgyakon, és az edények leírásakor való pontos rögzítésük által többletinformációkat nyerhetünk a készítés technológiájáról. Az egyszerű eszközöket találékonyan használták a különböző díszítési eljárásoknál is, ezért is fontos pontos ismeretük, megnevezésük.

Az üveggyártáskor használt alapanyagok meghatározzák a keletkező nyersanyag tulajdonságait, majd a segédanyagok ezeket módosítják. Néhányuk hatása a kész üvegtárgyon is szemmel láthatólag megfigyelhető (például a színezőké, a színtelenítő, homályosító anyagoké). Azok számára, akik üvegtárgyak elemzésével kívánnak foglalkozni nélkülözhetetlen ezen anyagoknak és az üvegben játszott szerepüknek pontos ismerete. Ezen eljárások ismeretének fontossága abban rejlik, hogyha pontosan ismerjük a gyártástechnológiát, annak nyomait megfigyelhetjük az elkészült tárgyakon, ez pedig nélkülözhetetlen a szakszerű, modern tárgyleírásnál. ${ }^{1}$

1 Külön köszönet illeti James Carcass üvegfújó mestert és feleségét Hegyi Bernadett iparművészt, akiknek segítsége nélkülözhetetlen volt a gyártástechnológia megismerésében, a részletkialakítások meghatározásában. 
A díszítésmódok pontos leírása, megnevezése ugyanezen okból fontos. Az edények különböző részeinek kialakítása változatos formájú lehet, különböző hőmérsékleten formálták az edények részeit. Különös jelentőséggel bír az edények peremrészének kialakítása, az, hogy még forró állapotban, vagy az edény kihűtése után alakították ki a peremet. Ezeknek a részeknek a gyártástechnológiát tükröző megnevezésére ezidáig kevés figyelmet fordított a hazai szakma, ezért fontos az erre vonatkozó egységes terminológia kidolgozása. Számos, üvegek feldolgozásával foglalkozó nemzetközi szakirodalom elején is megtalálható az adott nyelven az üveggyártással, leírással kapcsolatos szakkifejezések listája. Megfigyelhető ez a törekvés már D. Harden karanisi leletanyagot közlő munkájában is, tehát már a 20. század első felében felmerült az igény az üveggyártási eljárásokkal kapcsolatos terminológia létrehozására. ${ }^{2}$ Példáját azután sokan követték, különösen kézikönyvek, kiállítási katalógusok elején szerepel a szakterminusokat összegyüjtő rész. A teljesség igénye nélkül ide sorolható S. Cottam és J. Price kézikönyve, ${ }^{3}$ I. Lazar a szlovéniai anyagot bemutató publikációja, ${ }^{4}$ a Corpus delle Collezioni del vetro nel Veneto sorozat kötetei ${ }^{5}$ valamint a B. Caron és E. Zoïtopoúlou Lic Phil által készített katalógus, ${ }^{6}$ illetve számos kifejezetten az antik üveggyártással, műhelykérdésekkel foglalkozó mű. ${ }^{7}$ Az English Heritage pedig külön kiadványban gyűjti öszsze az üveggyártás régészeti vonatkozású kifejezéseit. ${ }^{8}$ Ezek a terminológiai összefoglalások sok esetben közlik az angol, német megfelelőit is a fogalmaknak. Ezt a tendenciát igyekeztem követni a terminusok meghatározásakor.

Az első fontos lépést a magyar nyelvű terminológia megteremtésében a római kor vonatkozásában Pánczél Sz. és Lázok K. munkája jelentette, amelyben az alapvető gyártási eljárások és néhány különleges üvegtípus magyar nyelvü elnevezését is megtaláljuk. ${ }^{9}$ Azonban a tárgyleíráshoz szükséges összes terminus technicus összefoglaló közlése eddig hiányzott a hazai szakirodalomból, a tanulmány kísérlet ennek pótlására, amely segítséget nyújthat az üveggel foglalkozni kívánó kutatók számára. A megnevezésekhez elsősorban az angol, német nyelvű szakirodalmat használtam fel, valamint Drescher K. magyar nyelvű üvegfújó szakmai ismeret tankönyvét.

\section{Az üveggyártás eszközei, berendezései}

fújócső: Általában vasból, ritkábban agyagból készült üreges cső, amely segítségével az üveget fújták. A manapság használatos fújóvas elnevezés kissé megtévesztő lehet, mivel az ókorban ez az eszköz nem feltétlenül csak vasból készült. ${ }^{10}$

tartórúd: A tartórúd szerepe, hogy lehetővé teszi az edény peremének problémamentes befejezését azáltal, hogy az edény alját egy kis darab forró üveggel a tartórúdhoz rögzítették, majd a fújócsövet leválasztották a cső végéhez közeli rész lehűtésével és lerepesztésével. Jellegzetes lenyomata marad az edény alján, amely általában gyűrű alakú, illetve jellegzetes kis

2 Harden 1936, XVIII.

3 CotTAM - Price 1998, 38-39.

4 LAZAR 2003, 17-24.

5 Bonomi 1996, 231-248; Toniolo 2000, 173-195; FACCHINI 1999, 283-300; ZAMPIERI 1998, 259-276; RAVAGNAN 1994, 267-300.

6 CARon - Zoïtopoúlou Lic Phil 2008, XXIII-XXXV.

7 Seibel 2008, 175-176.

8 PAynter - Dungworth 2011.

9 PÁNCZÉL - LÁZOK 2003.

10 blow-pipe: HARden 1936, XVIII; Glaspfeife, Röhre: SALDERn 2004, 218; fújóvas: Drescher 1972, 121; pipe: CARON - ZoÏTOPOÚlOu LIC PHIL 2008, XXXV; canna da soffio: BonOMI 1996, 241. 
benyomódás keletkezik használatakor az edény alján a rögzítéskor. A tartórúd szerepét játszhatja egy másik fújócső is, de általában tömör vasrudat használtak. ${ }^{11}$

görgetőlap: Sima felületű lap, valószínűleg kőből készült. Ma sík, csiszolt vaslapot alkalmaznak. Lényege, hogy a merítés után óvatosan kiemelik a fújócsövet, a sodróasztalra helyezik és ezen az üveget gurigatva formázzák, illetve később különböző díszítéseket vihetnek fel a segítségével (pl. márványozott díszítés készítése). ${ }^{12}$

olvasztótégely: Az üvegnek alapanyagaiból való összeolvasztására, valamint a nyersüveg rögök újraolvasztására használatos tégely, amelynek mérete függött az olvasztókemence nagyságától, az olvasztandó üveg mennyiségétől. Anyaga kerámia, vagy kő lehetett. A 19. század végéig főként ezekben olvasztották a nyersanyagot. Az ókori olvasztótégelyek általában a kerámia fazékformákra hasonlítottak. ${ }^{13}$

hütőkemence: Az elkészült üvegtárgyak feszültségmentesítéséhez szükség van arra, hogy a tárgyakat lassan, ellenőrzött körülmények között hűtsék le. Ellenkező esetben a keletkező felületi feszültség tönkreteheti az üvegedényt. A készterméket általában több óráig tartó folyamat alatt lassan hűtik le. A hütőkemence készülhet teljesen különállóan az olvasztókemencétől, vagy a fókemence (olvasztókemence) részét is alkothatja olyan módon, hogy egy különálló kamrát építenek az olvasztórészhez. A temperáló kemence is helyes elnevezés lenne, azonban szerencsésebbnek tartom a hűtőkemence elnevezést, mivel a temperáló kemence a modern üveggyártásban az üvegolvasztó kemencék üzemeltetéséhez szükséges különféle tűzálló anyagok előtemperálását, tömörre égetését szolgálja (például üvegolvasztó fazekakat). A tárgyak feszültségmentesítésére kamráshűtő kemencéket, illetve szalaghűtő kemencéket használnak manapság. ${ }^{14}$

olvasztókemence: Az üvegnek nyersanyagaiból való magas hőfokon való összeolvasztására, illetve a nyersüveg rögök újrahevítésére szolgáló kemencefajta. Főként kőből, agyagból, téglából épül fel. Mérete nagyon különböző, attól függően, hogy mekkora műhely tartozéka volt. A kisebb kidolgozó műhelyekben általában 1 méter körüli az átmérője, de a nagyobb nyersüveget gyártó központokban a több méter nagyságú átmérő sem ritka. ${ }^{15}$

kádkemence: Az olvasztókemencék egyik fó típusa. Ebben az esetben a kemencébe be van építve egy központi tartály, téglából, vagy kőből, amelyben a nyersüveget olvasztják. Az első, kisméretű példányait a római korból, az 1 . századból ismerjük. ${ }^{16}$

olvasztótégelyes kemence: A római korban a másik, nagyon gyakori olvasztókemence típus. Általában kisméretű, 1 méter körüli átmérőjü, kör alakú vagy ovális kemence, alul a tűztérrel, felette egy padozattal körben a kemence fala mentén, amely az olvasztótégelyek elhelyezésére szolgált. ${ }^{17}$

11 pontil: Harden 1936, XVIII; tartórúd: Drescher 1972, 122; pontil, punty: Caron - ZoÏtopoúlou Lic Phil 2008, XXXV; Hefteisen: Fischer 2009, 145.

12 marver: HARDEN 1936, XVIII; marvered block: SCHUleR 1959, 116-122; marver: PAYNTER - Dungworth 2011, 31; görgető asztal: Drescher 1972, 124; marver, marbre: CARON - ZoÏTOPOÚLOU LIC PHIL 2008, XXII, XXXV; Marbel (Wälz) Platte: SEIBEL 2008, 176.

13 pot: Harden 1936, XVIII; crucible: Paynter - Dungworth 2011, 17; Tiegel: SeIBel 2008, 175; crogiolo: Bonomi 1996, 244; creuset: Foy - NenNa 2001, 501.

14 kamráshütó-kemence: DrESCHER 1972, 47-49; annealing oven/furnace: PAYNTER - DUNGWORTH 2011, 8; annealing kiln: CARon - Zö̈topoúlou LIC PhIL 2008, XXII; four de refroidissement: CARON - ZoÏTopoúlou Lic PhIL 2008, XXXIV; Kühlofen: SeIBEL 2008, 175; lehr: TAYLOR - Hill 2008, 251.

15 melting furnace: PAYNTER - Dungworth 2011, 8; Glasschmelzofen: Fischer 2009, 145.

16 tank furnace: PAYNTER - Dungworth 2011, 7; Wannenofen: Fischer 2009, 145; four à bassin: Foy - NennA 2001, 502.

17 pot furnace: PAynter - Dungworth 2011, 32; Hafenofen: SeIbel 2008, 175; four à creusets: Foy - NenNA 2001, 502. 


\section{Az üveggyártás alapanyagai}

alapanyagok: Az alapanyagokra jellemző, hogy az üveg összetételében nagyobb mennyiségben vannak jelen és meghatározzák a keletkező üveg tulajdonságait, a segédanyagok aztán ezeket módosítják, vagy az olvasztási folyamatban játszanak szerepet. Az alapanyagok csoportját üvegképző oxidok és módosító oxidok alapanyagainak csoportjába sorolhatjuk. A módosító oxidok pedig tovább oszthatók olvasztó oxidokra és tartósító oxidok alapanyagaira. ${ }^{18}$

üvegképző oxidok: Ezek az anyagok az üveges állapot előidézői, vagyis az üveg kristállyá való alakítását teszik lehetővé. Ez a folyamat a devitrifikáció, amely a lehülés alatt, vagyis a folyékonyból a szilárd halmazállapotba való átmenetkor jelentkezik, amikor a hülés folyamata lassú. Ezt a fogalmat gyakran tévesen használják amikor az antik üveg pusztulásáról, lebomlásáról beszélnek. Az ókorban a homok, nagyrészt a tengerparti homok játszotta az üvegképző oxid szerepét. A kvarchomokon kívül rácsképző anyag még a $\mathrm{B}_{2} \mathrm{O}_{3}$, a $\mathrm{P}_{2} \mathrm{O}_{5}$ és az $\mathrm{Al}_{2} \mathrm{O}_{3}$, de ezek az ókori üveggyártásban nem fordultak elő. ${ }^{19}$

olvasztó oxidok: A módosító oxidok nyersanyagain belül az olvasztó oxidok feladata, hogy csökkentsék az olvadási hőfokot. A leggyakoribb a szóda és a hamu. Amikor az olvasztószert felmelegítik, felbomlik és reagál a homokkal (kb. $1700{ }^{\circ} \mathrm{C}$-on) és alkáli-szilikáttá alakítja, amely már száz fokkal alacsonyabb hőmérsékleten olvad. ${ }^{20}$

tartósító oxidok: A tartósító oxidok vagy stabilizátorok, az üvegnek stabilitást adó összetevők, vagyis a szerkezet keménységét növelik, hogy ellenálló legyen a légköri, külső hatásoknak. Az első üvegkészítők nem voltak tudatában ezeknek a tulajdonságoknak, így ezeket az anyagokat közvetetten keverték az üvegbe a nyersanyag részeként felhasznált homok vagy tengeri növények hamvának hozzáadásával. Ilyen tartósító oxid a kálciumoxid $(\mathrm{CaO})$. A természetben nagy mennyiségben, tisztán előforduló vegyületei közül a kálciumkarbonát (Ca$\mathrm{CO}_{3}$ ) a legjelentősebb üveggyártási szempontból. A kálciumkarbonát mészpát, kréta és márvány elnevezés alatt is ismeretes. ${ }^{21}$

segédanyagok: A segédanyagok az alapanyagok tulajdonságait módosítják, vagy az olvasztási folyamatban játszanak szerepet. Az üveggyártás segédanyagait feloszthatjuk tisztulást segítő, színtelenítő, színező, homályosító, olvasztást gyorsító anyagokra. ${ }^{22}$

színtelenítő anyagok: Az üveggyártás céljaira felhasznált nyersanyagok többé-kevésbé szenynyező anyagokat tartalmaznak. Különösen jelentős ilyen szempontból a homok vasoxid tartalma, amely az üvegnek zöldes színt kölcsönöz. A színtelenítő anyagok feladata ezt a szenynyező anyagok által okozott tónust semlegesíteni, eltüntetni. Ezáltal nyerhettek színtelen üveget. Leggyakrabban mangánt és antimont használtak erre a feladatra. ${ }^{23}$

színezők: A színezők olyan kémiai elemek az üveg nyersanyagában, amelyek meghatározzák annak színét. Néhány már az alapanyagokban megtalálható (vas, szén), míg másokat tudatosan adnak a nyersanyaghoz. Alapjában háromféle eljárás adott a színezésre. A színezőanyag az alapüvegben feloldódik, az alapüvegben apró szemcsékben kiválik, de festék alakjában is

18 alapanyag: Drescher, 1972, 94-96; principal constituent: COTTAM - PriCE 1998, 10.

19 üvegképző oxidok: Drescher 1972, 94-95; former: COTTAM - PRICE 1998, 10.

20 olvasztó oxidok: Drescher 1972, 95-96; flux: COTTAM - Price 1998, 10.

21 tartósító oxidok: Drescher 1972, 95-96; stabiliser: COTTAM - Price 1998, 10.

22 segédanyagok: Drescher 1972, 99.

23 színtelenítők: Drescher 1972, 99-100; decolourisers, decoloranti, Entfärbungsmittel: LAZAR $2004,153$. 
felvihető (lásd: díszítés). Réz hozzáadásával nyerhetünk vörös, zöld és kék tónust, mangán adalékkal bíbor, barna és fekete árnyalatot kapunk, míg a kobalt kék színt eredményez. Az ólom, vagy antimon sárgás színt ad. ${ }^{24}$

bog: Egy adag olvasztott üveg, amelyből fújócsőre, vagy vasrúdra merítve készterméket készítettek. Ennek mennyisége a készítendő termék nagyságától függően változott. ${ }^{25}$

banka: A banka a fújócső végén elhelyezkedő fújt üveggolyó, amelynek segítségével a fúvócső merítési felületét lehet megnövelni, ezáltal alkalmassá téve nagyobb mennyiségü üvegolvadék felvételére (Fig. 2). ${ }^{26}$

nyersüveg: Az üvegnek fő nyersanyagaiból, homok, mész és alkália keverékéből álló, alacsony hőfokon való összeolvasztása által keletkező alapanyaga. A kétlépcsős nyersanyaggyártás első lépcsőjében keletkező alapanyag, amelyet darabokra törve szállítottak a kidolgozó műhelyekbe és valószínűleg ún. elsődleges, nyersanyagot gyártó műhelyekben készítettek el az ókorban. ${ }^{27}$

törött üveg: Mind régészeti, mind írott forrásokkal rendelkezünk arra vonatkozóan, hogy a törött üveget szisztematikusan gyűjtötték és újra felhasználták az 1. századtól mindenképp. A törött üveg hozzáadása segítette a nyersanyagok összeolvadását és meggyorsította az olvasztási folyamatot. Az összegyüjtött törött üveg tartalmazta üvegedények és ablaküvegek darabjait, valamint a mủhelyekben a gyártás során visszamaradt hulladékot. ${ }^{28}$

edénygyártási hulladék: Az üvegtárgyak készítésekor, fújásakor lecseppent üvegszálak, cseppek, amorf üvegdarabok. Ide sorolhatóak a fújócsövön maradt hengeres, vagy kupak alakú egyik felükön éles széllel rendelkező darabok, amelyek az edénynek a fújócsőről való leválasztásakor keletkeztek. ${ }^{29}$

irizáció: Az üveg régészeti közegben való elszíneződése. Ez az üveg bomlása miatt alakul ki, ugyanis az anyag reagál a földben lévő elemekre, például vasra, mangánra. A folyamat tulajdonképpen szivárványszínek kialakulását jelenti az üveg felületén, amely az üveg felszínén történő fénytörés eredményeként alakul ki. A sérült felület hámlik a felszínen, ami finom, szivárványos burok formájában ismerhető fel. ${ }^{30}$

hammonitrum: A két lépcsőben történő üveggyártás során az első lépcső után keletkező anyag, az alapvető alapanyagok, homok, mész és alkália keverékéből áll, amelyet összeolvasztás után lehütöttek, majd darabokra törtek, hogy a különböző szennyeződéseket, valamint a megkeményedett habszerü felsőrészt eltávolítsák. Ez a folyamat kevesebb, mint 750 ${ }^{\circ} \mathrm{C}$-on történt. Ezután újrahevítették az anyagot (1200 ${ }^{\circ} \mathrm{C}$ körül), üvegrögöket, üvegbogokat alakítva ki, amelyeket így tároltak a későbbi feldolgozásig. Az ókori üveggyártás valószínüleg kétlépcsős volt, ahogy azt Pliniusnál is olvashatjuk (Plin., Nat. Hist., 36.194).

24 színezők: Drescher 1972, 100; colouring agent: CotTAM - Price 1998, 10; coloranti, Färbmittel: LAZAR 2004, 153.

25 Glasposten: Fischer 2008, 145; Külbel: SeIBEL 2008, 176; paraison: HARDEN 1936, XVIII; gather, gob: CotTAM - PRICE 1998, 38.

26 banka: DRESCHER 1972, 157.

27 Primärglas: Fischer 2009, 145; batch, frit: HARden 1936, XVIII; raw material: CotTAM - Price 1998, 10; frit, fritta: BoNOMI 1996, 244; miscela vetrificabile: BONOMI 1996, 245.

28 cullet: Paynter - Dungworth 2011, 10 ; Altglas: Fischer 2009, 145; groisil, calcin: Foy - Nenna 2001, 502; Mart., Epig. $1.41 .3-5 ; 10.3 .3-4$.

29 moile, moil: CotTAM - Price 1998, 39; Kappe: Seibel 2008, 176.

30 irisation: LAZAR 2004, 153-160; irisation, iridescence: CARON - ZoÏTopoúlou Lic PhIL 2008, XXII, XXXV; iridescenza: BONOMI 1996, 245. 

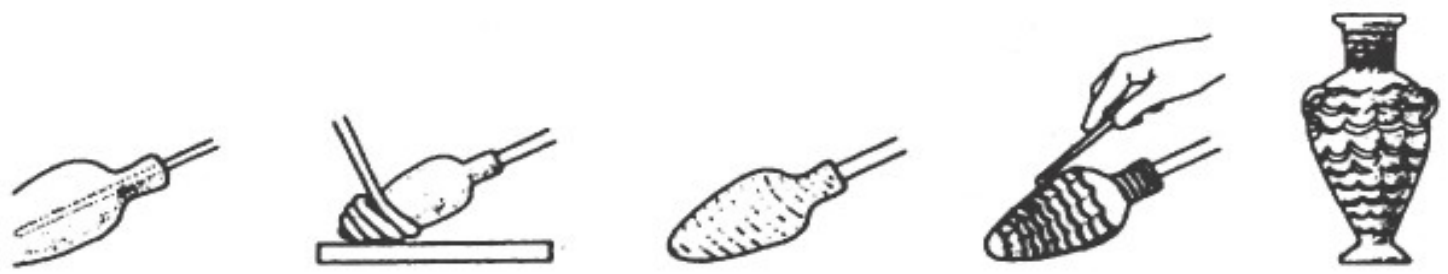

1
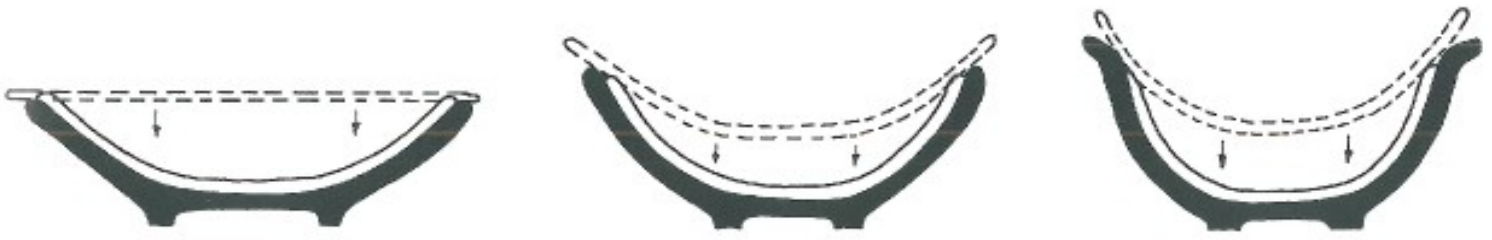

2

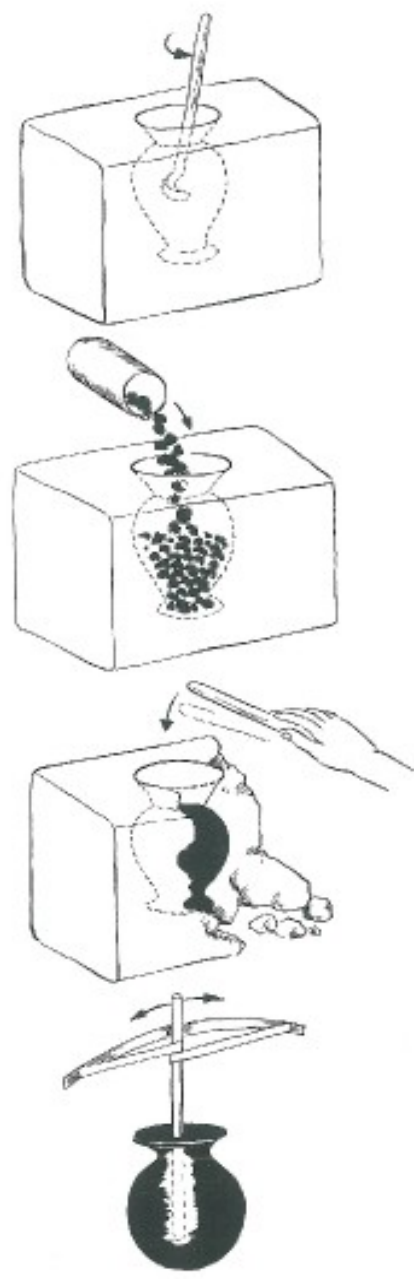

4

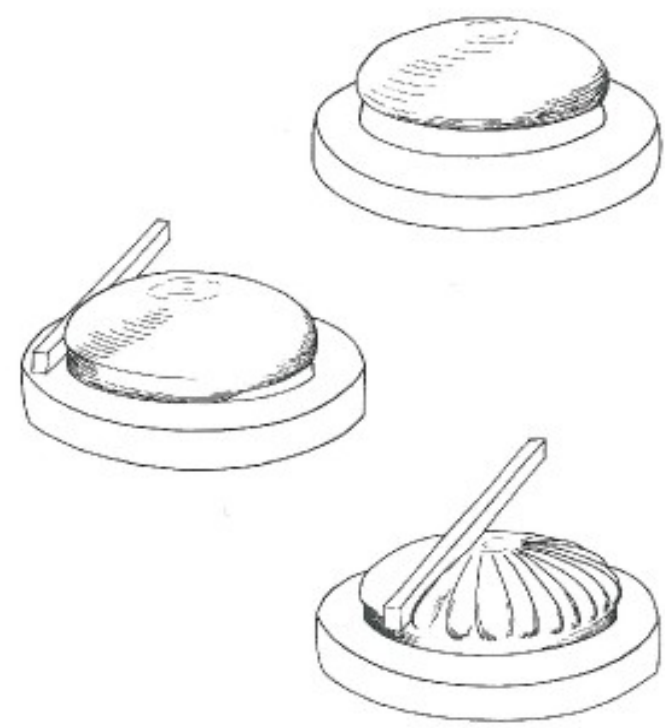

3

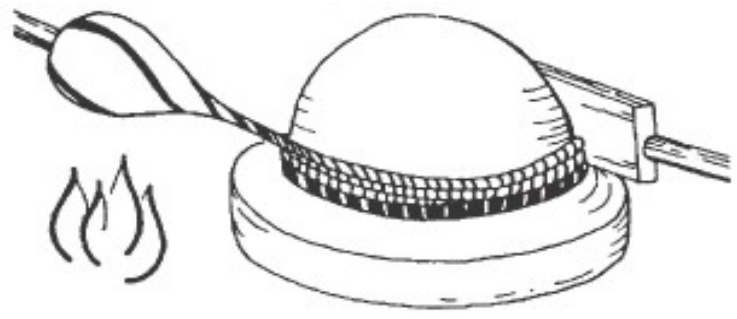

5

Fig. 1. 1. Homokmagon formázott üvegedény gyártása - Producing of a core-formed vessel (SALDERN 2004, 8). 2. Öntés laprogyasztással - Sagging (STERN 1994, 69). 3. Bordás tál készítése öntéssel - Producing of a ribbed bowl (STERN 1994, 137). 4. Chip-casting technika - Chip-casting technique (STERn 1994, 51). 5. Mozaikedény készítése fazekaskorongon - Spinning on potter's wheel (SALDERN 2004, 134). 
nátronüveg: A nátronüveg hevítésekor szódát vagy nátront adtak az alapanyagokhoz. Az ókori üveg nátronüveg volt és jobban ellenállt a külső hatásoknak, mint a káliüveg, amely a középkorban terjedt el. Ez a fajta laza szerkezetű, jól és egyenletesen színezhető, jó idegenanyag befogadó. ${ }^{31}$

káliüveg: A káliüveg magas káliumtartalommal rendelkezik, olvasztásánál hamut használtak. Mindenekelőtt a középkorban alkalmazták. Kevésbé ellenálló a légköri hatásoknak, mint a nátronüveg, de csillogóbb felületü, könnyen csiszolható és fényezhető. A típus kedvez a megmunkálásnak, tartósabban képlékeny, míg a nátronüveg hamarabb dermed. Fém-oxidokkal való színezése nehézkesebb, de élénkebb színeket eredményez. Más néven erdei üvegnek is szokták nevezni. ${ }^{32}$

\section{Az üveggyártás eljárásai}

homokmagon formázás: A homokmagon formázás a legrégebbi üvegedény gyártási technika, amely szélesebb körben elterjedt (Fig. 1.1). Elsősorban a hellénizmus ellőtt volt használatos, de alkalmi megjelenése később is lehetséges. A folyamat lényege, hogy egy homok magot alakítottak ki, amelyet merítés vagy tekercselés útján üvegmasszával vontak be. Ezután ezt felmelegítették és tovább alakították, amelyet szabad kézzel, fa-és fémpálcikákkal, késekkel, éles, sarkos kövekkel és kiégetett formaagyag testekkel végezték. Díszítményként színes üvegszálakat, rudakat lágyított állapotban a felületre nyomkodtak, majd simító szerszámokkal és sima asztallapon hengereléssel egymáshoz forradó szalagokká lapították. ${ }^{33}$

öntés, préselés: Általánosan használt gyűjtőfogalom olyan üvegedény gyártási módszerekre, ahol semmilyen munkafolyamat során nem alkalmaztak fúvást. A pontos folyamatok leírása bonyolult, változatos módszereket és különböző szerszámokat használtak az eltérő hőmérsékleteken történő megmunkálás során. Ennél a technikánál a felhevített alapanyag lassú folyását használták fel úgy, hogy ezt különböző öntőmintákba helyezték. Az üveg a nehézségi erő hatására kitölti a forma alakját. A folyamat gyakran több órát vett igénybe. Az öntött edények onnan ismerhetőek fel, hogy finom horizontális polírozási nyomok figyelhetőek meg a belső és néha a külső felületen. Elsősorban polikróm, erősen színezett monokróm (kék, zöld) és színtelen öntött edények ismertek. A technika alkalmazásához körülbelül $1150{ }^{\circ} \mathrm{C}$ körüli hőmérsékletre kellett hevíteni az alapanyagot és a forma előmelegítése is szükséges volt. ${ }^{34}$ Legkorábban használt formája az ún. chip casting, amikor kis darabokra tört üvegszilánkokkal töltöttek meg egy formát, majd azzal együtt hevítették kemencében (Fig. 1.4). Hátránya, hogy tömör tárgyat eredményez, amelynek belsejéből ki kellett vésni a felesleges üveget. Ezzel az eljárással elő tudtak állítani opak és áttetsző üveget is. ${ }^{35}$ A viaszveszejtéses bronzöntés mintájára később felfedezték, hogy többrétegű formába öntéssel, amelyet viasz modell köré formáztak, elkerülhető, hogy az üvegedény belső részét véséssel kelljen eltávolítani. Ennek továbbfejlesztett változata a nyitott formába öntés volt, amikor egy lapos, konvex formába vékony rétegben üveget öntöttek. ${ }^{36} \mathrm{~A} \mathrm{Kr}$. e. 2. századtól alkalmazták a laprogyasztás technikáját széles körben (Fig. 1.2). Ennél az eljárásnál szükség volt egy előre gyártott üveglapra, amely azután egy homorú forma felett hevítve fel-

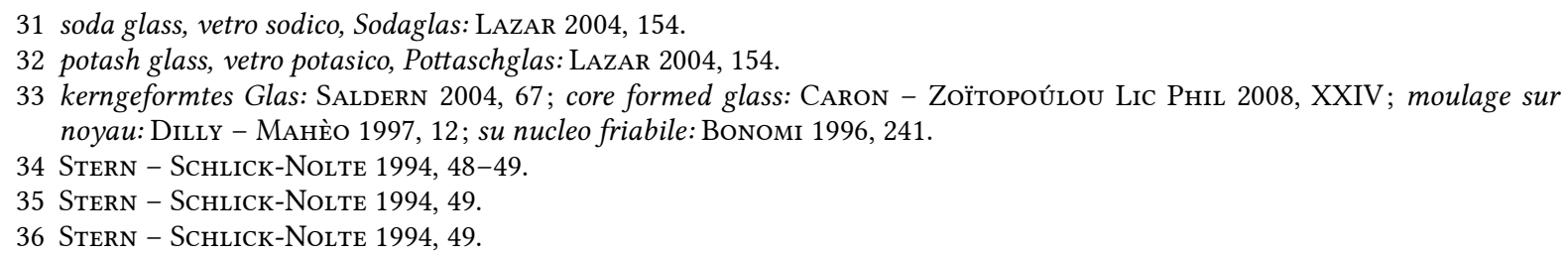


vette annak alakját. ${ }^{37}$ Lehetséges volt az előre gyártott üveglapot domború formára is ráolvasztani, mialatt a lassan lefolyó masszát még különböző eszközökkel tudták alakítani. Ez az alakítás úgy volt a legkönnyebb, ha a formát forgó korongra helyezték (fazekaskorongon való formázás) (Fig. 1.5). ${ }^{38}$ A hellénisztikus kortól használták szélesebb körben az eljárást. A legismertebb edényfajta, amit ezzel az eljárással gyártottak az 1. században rendkívül népszerü bordás tál és a különböző mozaikedények. ${ }^{39}$

bordás tálak: A legismertebb edényfajta, amit ezzel az eljárással gyártottak az 1. században rendkívül népszerü bordás tál volt. ${ }^{40}$ Ennek pontos gyártási folyamata is vita tárgya, de nagy valószínűséggel úgy állították ezeket elő, hogy egy forró üvegkorongba résekkel ellátott fémlapot nyomtak, így az üveg átvette ennek mintáját. Elképzelhető, hogy a felhevített üveglapra fémrudakat nyomva készült az edénytípus (Fig. 1.3). Ezután helyezték rá a domború mintára, majd újra felhevítették, amelynek következtében a külső felület fényes lett. Amikor kihűlt polírozták a belső felületet, amely az öntőmintával kapcsolatba került, valamint a külső felületen a bordák tetejét. Az eljárás nyomán a felületek kezelésének különös kombinációja jött létre, amelynek köszönhetően ez az edénytípus akár kis darabokból is könnyen azonosítható.

mozaikedények: olyan többszínü öntött edények, amelyek csavart, vagy rétegelt üvegrudakból és összetett üvegrudak keresztmetszeteiből készültek. Ezeket összefoglalóan mozaikedényeknek nevezhetjük, de a gyártási eljárásokat megkülönböztetve több fajtára oszthatjuk okket. ${ }^{41}$

szalag- vagy spárgamozaik edény:42 a Kr. e. 1. - Kr. u. 1. században gyakori. ${ }^{43}$ Többszínű üvegrudakat egymás mellé helyeztek és összeolvasztottak, majd ezt öntőmintára fektetve addig hevítették, amíg a kívánt alakot elnyerte. Az üvegrudaknak sima, egyszeresen vagy kétszeresen csavart szálaik voltak. Ezeket a áttetsző alapra rakták, majd újrahevítették. A peremet egyszeresen csavart kék és fehér színü üvegrúdból képezték ki. Alkalmanként aranyfólia szalagokat is belefoglaltak színtelen üveg rudakba és olvasztottak szalagmozaik edényekbe. Ennek az edényfajtának több típusa van, attól függően, hogy hogyan rendezték el az üvegrudakat. ${ }^{44} \mathrm{Az}$ edény állhatott egymással párhuzamos szalagokból, egymásra merőleges rudakból, vagy akár egy spirálisan felfutó rúdból. Ha ezek a kompozit üvegrudak azonos színű üvegből készültek egy jellegzetes hálómintát eredményeztek a kész tálon. Ezek az ún. reticella edények, amelyeknek két fajtáját ismerjük. ${ }^{45}$ Egyrészt készülhettek reticella rudak hoszszanti darabjainak egymás mellé helyezésével és újrahevítésével (szalag reticella edények). ${ }^{46}$ A második fajta a spirális reticella edények csoportja, amikor az edény egy, hosszú reticella rúdnak a forma köré való spirális felcsavarásával keletkezik. Ez a gyártási eljárás az ún. fazekaskorongon való „fonás” technikája (Fig. 1.5). ${ }^{47}$

37 STERN - SCHLICK-Nolte 1994, 68-69.

38 STERN - SCHLICK-NOLTE 1994, 72-73.

39 formgeschmolzenes Glas: SALDERN 2004, 161; casting: CotTAM - PRICE 1998, 11; öntés: Drescher 1972, 150; geformtes, formgeschmolzenes Glas: RüTti 1991, 26; verre pressé: Dilly - MAнÈo 1997, 12; colatura a stampo: BonOMI 1996, 240.

40 Rippenschalen, ripped bowl, pillar-moulded bowl: STERN - SCHLick-Nolte 1994, 137; CotTAM - Price 1998, 44.

41 Mosaikglas: Stern - Schlick-Nolte 1994, 69; Cottam - Price 1998, 11.

42 PÁNCZÉL - LÁZOK 2005, 165.

43 Streifenmosaikglas, strip and lace mosaic: Stern - SChlick-Nolte 1994, 69; CotTAM - Price 1998, 11.

44 Cottam - Price 1998, 11.

45 STERN - SChlick-Nolte 1994, 71. A kifejezés az olasz „reticello” szóból ered.

46 Stern - Schlick-Nolte 1994, 71.

47 Stern - Schlick-Nolte 1994, 71. 
virágmintás mozaikedény: ${ }^{48}$ a mozaikedény készítésének másik lehetséges módja a „virágos mozaik" készítés. ${ }^{49}$ A két vagy többszínű összetett üvegrudak keresztmetszeteiből készültek ezek a virághoz hasonló minták Általában egy erősebb színt használtak az edény alapjának elkészítéséhez, majd erre kerültek a különböző virágminták. Gyakran különböző színekből alakították ki a virág közepét és szirmait. Az alap színei általában a lila, a bíbor, a sötétkék, a sötétzöld és a sötétsárga. A virágokat világossárga, halványkék, halványzöld és fehér színből készítették. ${ }^{50}$
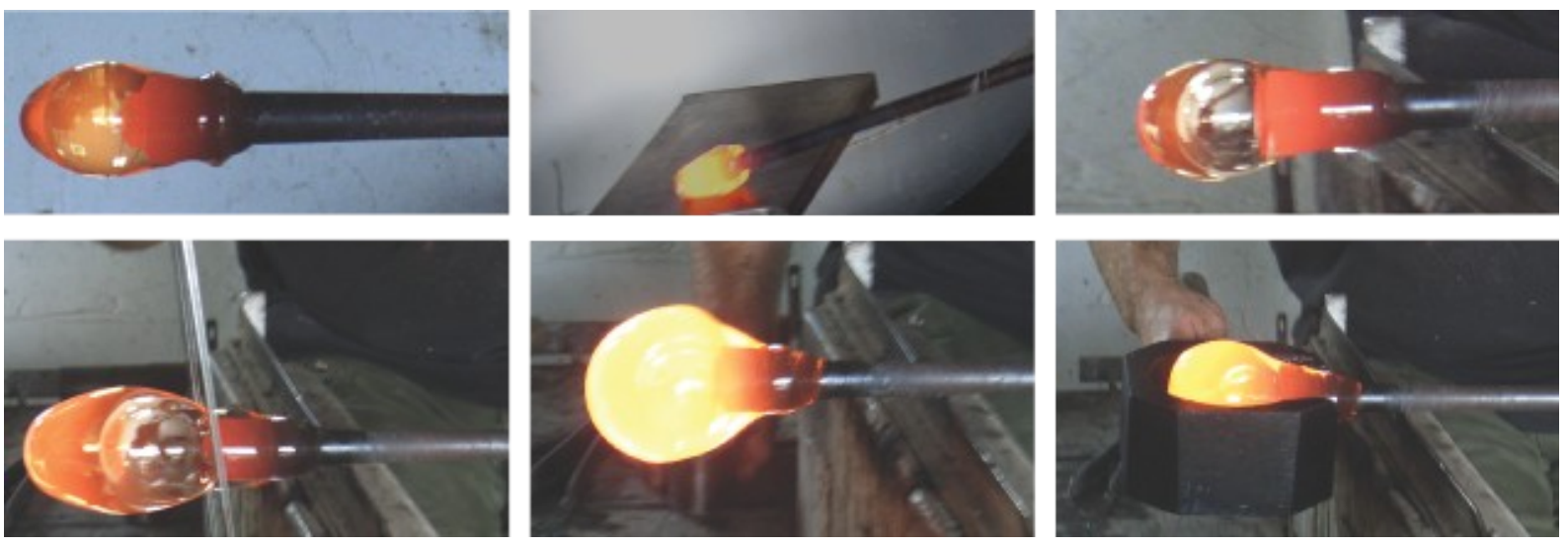

Fig. 2. A szabadon fújás munkafolyamatai - Free blowing technique.

szabadon fújás: A római kortól uralkodó technikai eljárás, amelynek lényege, hogy az izzó üvegolvadékot levegő segítségével üreges testté képzik ki, amely lehet szimmetrikus és asszimetrikus megjelenésű (Fig. 2). ${ }^{51} \mathrm{~A}$ folyamat lényege, hogy az üvegolvadéknak a fújócsőre való merítése után óvatosan kiemelik a fújócsövet és a sodró asztalra helyezik, ezen az üveget görgetve formázzák. A sodróasztalon való formázás nemcsak az alakját adta meg az olvadéknak, hanem kissé le is hütötte annak felületét, ezáltal a fújás során keletkező légbuborékok megelőzhetőek voltak. Ez a fajta megmunkálás nem csak sodróasztal segítségével végezhető el, hanem különböző méretű, fából készült, kanál alakú formában is. Ebben az esetben a művelet neve kanalazás. Meg kell említenünk a nyakbevágás műveletét, amely megelőzheti a kanalazást. Ekkor a fújócsőre merített üvegbogot közvetlenül a csővég alatt csípőfogóval elvékonyítják. Ez megkönnyíti a készre gyártás után a csőről való leütését a tárgynak, amely ennek hiányában gyakran elrepedhet. A nyakbevágás teszi lehetővé azt is, hogy a bog zárt formába való befújásra alkalmas legyen. ${ }^{52}$ A következő művelet az úgynevezett zsákképzés, amely egy előfúvási munkafolyamat. Ezután következett a fújási szakasz, amely közben a fújócsövet horizontálisan tartották és folyamatosan forgatták, kivéve, ha a formát nyújtani illetve tömöríteni akarták, mert ekkor vertikálisan fogták a rudat, mint ma a formába fújásnál. Amikor a kívánt formát elérték az edény alját egy kis darab forró üveggel a tartórúdhoz rögzítették, majd a fújócsövet leválasztották a cső végéhez közeli rész lehủtésével és lerepesztésével. ${ }^{53} \mathrm{Ez}$ jellegzetes lenyomatot hagy az edény alján. Általában félkörívben egy kis üvegdarab kitörik, de az is lehetséges, hogy a tartórúdat rögzítő üvegcsepp maradványa figyelhető meg az edény alján (Fig. 3).

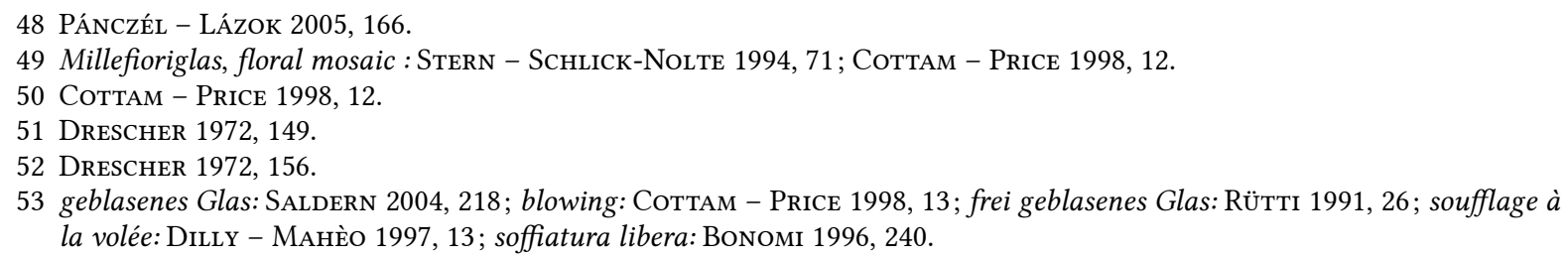



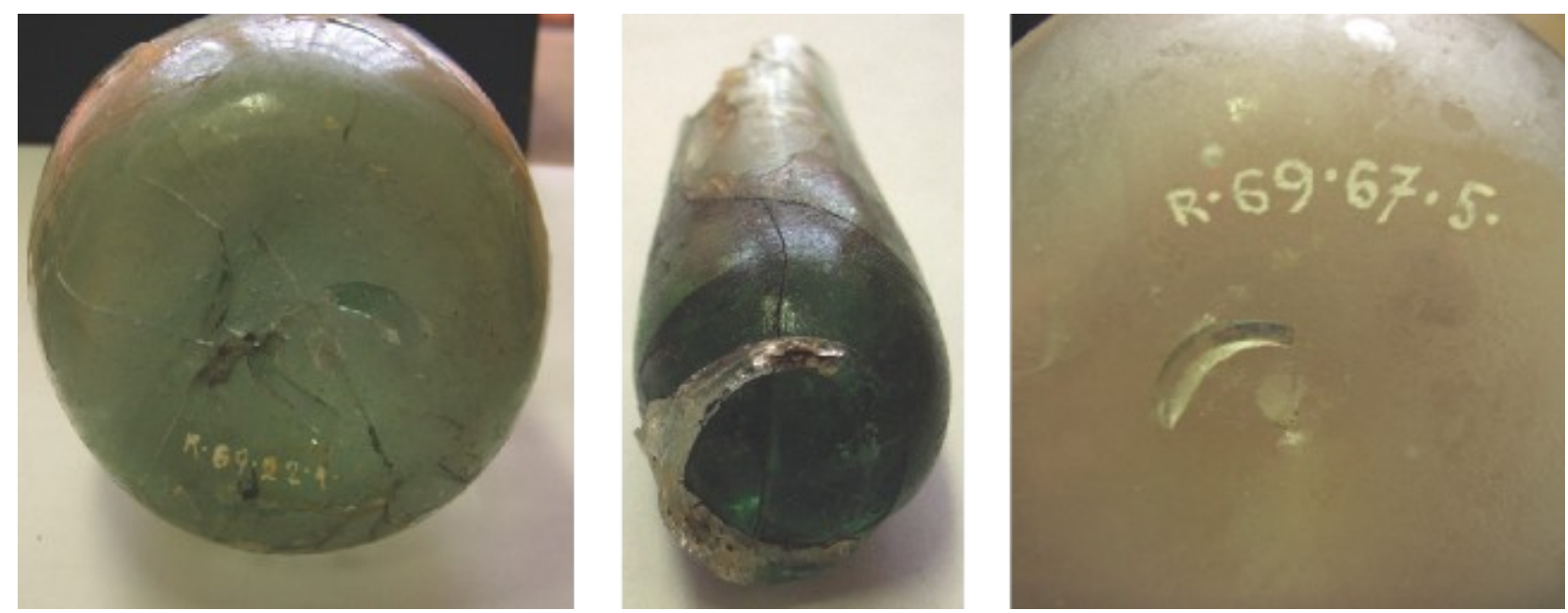

Fig. 3. Tartórúd rögzítésének nyoma - Pontilmarks.

formába fújás: Ennél az eljárásnál a fújócsövön lévő merített anyagot egy- vagy többrészes formába fújják bele, ezáltal az edénynek meghatározott formát és díszítést adnak. Ezek a formák ritkán maradnak meg, valószínűleg fémből, agyagból, kőből készülhettek. A legelterjedtebb a több darabból álló minta, amely levehető volt az elkészült tárgyról (Fig. 4). A leglényegesebb tulajdonsága viszont az, hogy újra felhasználható volt. A forma anyagának minőségétől függően sorozatgyártásra volt alkalmas. Gyakran lehetséges az azonosítása ugyanazzal az öntőformával, illetve öntőforma sorozattal gyártott üvegeknek. A minta belső felületén lévő dekoráció domború díszítményként jelentkezett az elkészült darab külső felületén. A formába fújt edény belső felülete a külső felület kontúrját követi. A minta darabjainak illeszkedésénél megfogható függőleges szegélyek keletkeztek az edényen, ez a legjellemzőbb tulajdonsága a formába fújt tárgyaknak. Vannak azonban egyrészes formák, ahol természetesen ez a szegély nem látható ilyen egyértelműen, például néhány késő római edény esetében. Egyrészes formába fújt a késő római pohárformák nagy része, a forma teteje jellegzetesen ívelt peremük alatt helyezkedett el. A legismertebb formába fújt római kori edénytípus a hasábos testű palack. ${ }^{54}$
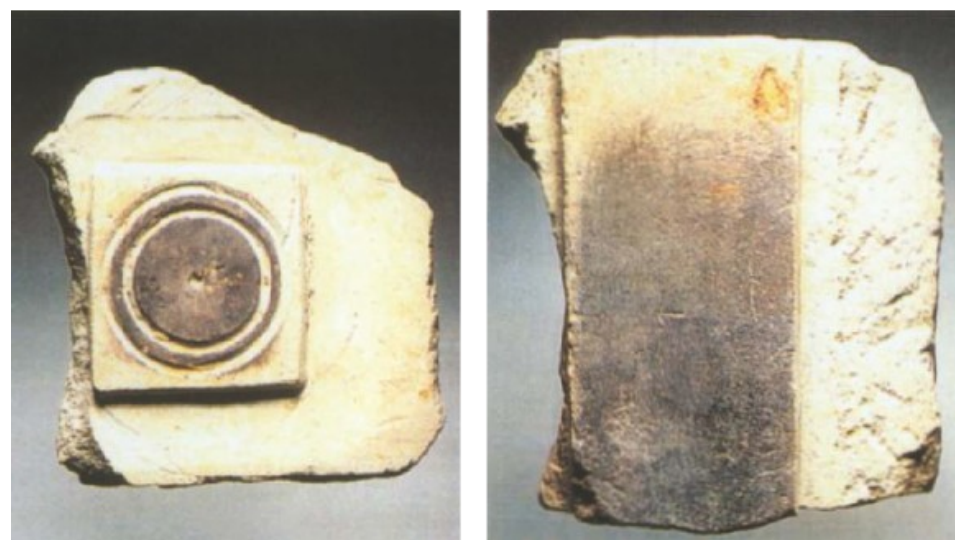

Fig. 4. Kőből készült formák töredékei - Fragments of a stone mold. (http://www.romanglassmakers.co.uk/beakers.htm).

54 formgeblasenes Glas: SALDERN 2004, 231; mould-blowing: COTTAM - PRICE 1998, 12-13; in eine mehrteilige Form, oder in eine Halbform geblasenes Glas: RüTti 1991, 26; soufflage au moule: Dilly - MAHÈo 1997, 14; soffiatura a stampo: BonoMI 1996, 241. 


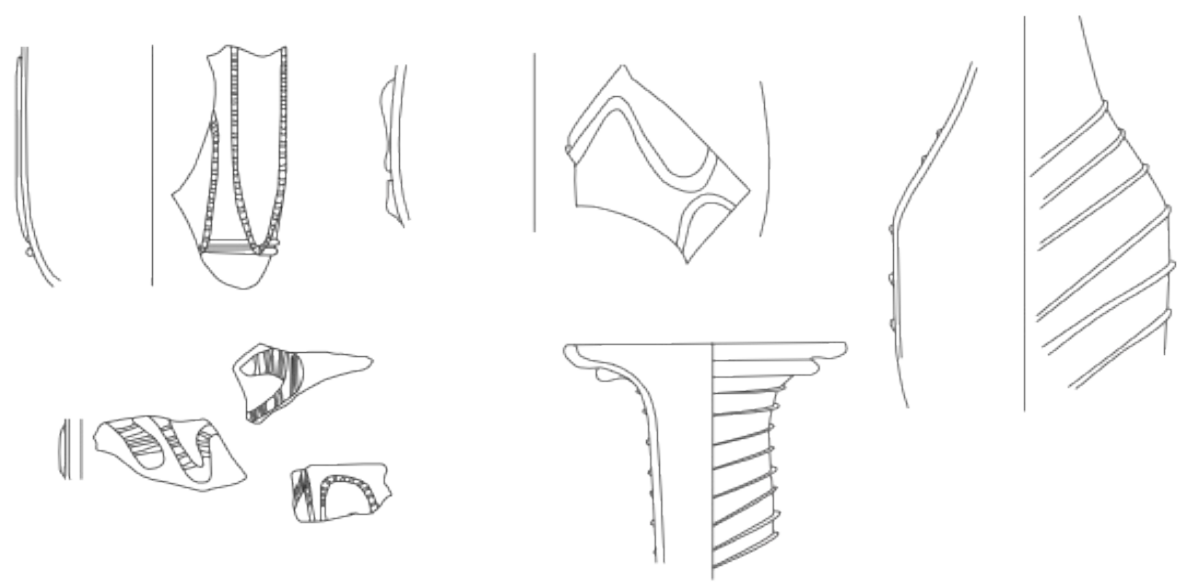

1

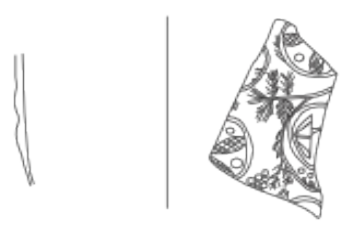

2

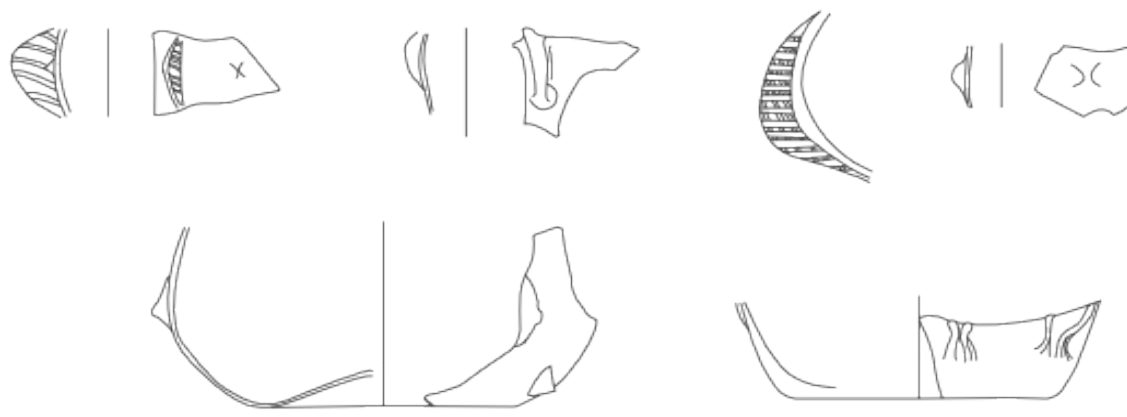

3
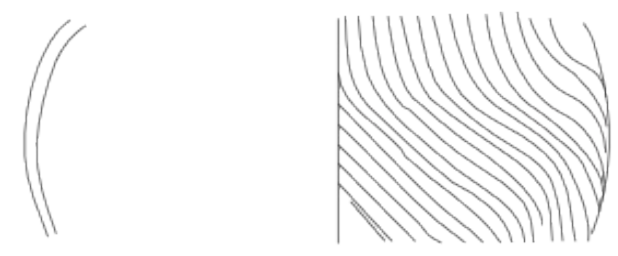

4

Fig. 5. 1. Plasztikus szálrátét díszítések - Applied trails decoration. 2. Ornamentális vésett díszítés - Ornamental cutting decoration. 3. Az edény testéből kialakított, kicsípett díszítések - Lugs and small projections, which were pinched out from the wall of the vessels. 4. Optikai fújt díszítés - Optic-blowing design. 
optikai fújás: Az eljáráshoz egy csőszerủ mintát használtak, amelyet a merítés után a lényegi megmunkálás és fújás előtt vettek igénybe, hogy a segítségével bordákat, vagy más díszítést alkalmazzanak az üveg felületén, amely a későbbi fúvás után kidomborodó mintaként jelentkezett megnagyobbodott formában, ezért körvonalai kevésbé voltak élesek (Fig. 5.4). Ezt a díszítési módot kancsókon, tégelyeken, tálakon és más edényeken használták. Jellegzetes példája a késő római korban az edény testén ferdén elhelyezkedő kannelurákkal díszített palackok, korsók csoportja. ${ }^{55}$

\section{Az üveggyártás díszítési eljárásai}

\section{Forró díszítési technikák}

Olyan díszítési eljárások gyűjtőfogalma, amelyek az üveg készítésével egy időben, annak még forró állapotában jönnek létre. ${ }^{56}$

plasztikus szálrátét díszítés: Az 1. századtól a 4. századig divatos a vízszintesen illetve spirálszerűen húzódó üvegszál dísz, amelyet a még forró edényre vittek fel, néha márványozott díszítéssé alakítva át (Fig. 5.1). A kupák, tálak és kannák pereme alatt vízszintesen végigfutó egyes szál a 2-3. század edényeinek jellegzetessége (Fig. 7.6), míg a spirálszerűen feltekert üvegszálak behálózhatták az egész edényt, illetve a nyakon körbefutó lánc-, cikkcakk-, és hurokdíszítést képezhettek (Fig. 7.7-10). Ennek a módszernek legkidolgozottabb formája a szabálytalanul felhelyezett ún. kígyózó szál, amely a 2-3. század tipikus díszítőmotívuma. ${ }^{57}$

plasztikus petty díszítés: A 3-5. században cseppekkel, pettyekkel díszítették az edény falát (főleg kupákat és poharakat). A cseppek és az edény egyformán forró volt, így a gömböcskék összeolvadhattak a felszínnel (Fig. 7.1-3). Alapvetően két variáció létezik, egyrészt egyszínü (mindig kék) cseppdíszítés, vagy két illetve többszínű petty/cseppdíszítés. ${ }^{58}$ Gyakran kombinálták a technikát kerékvésett szalagokkal, amelyek sokszor ráfutnak a pettyek felszínére is, illetve bekarcolt vonaldíszítéssel is alkalmazták együttesen ezt a fajta díszítést (Fig. 6).
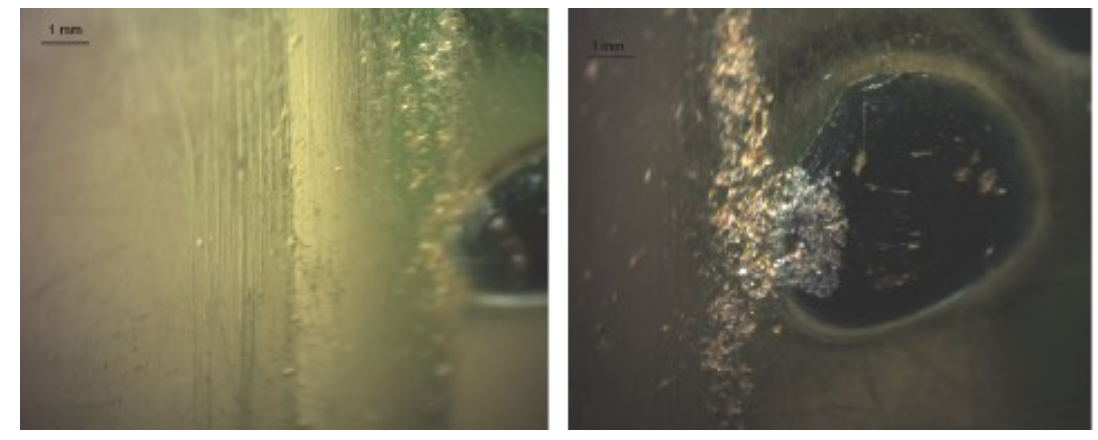

Fig. 6. Pettyes rátétdíszek, kerékvésett vonalakkal és bekarcolt vonaldísszel - Applied blobs with wheel-cutting lines and abrasion band.

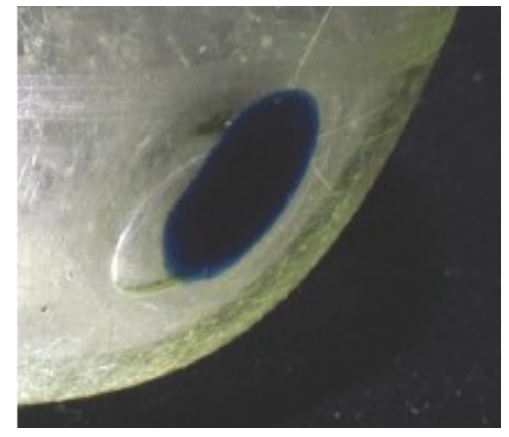

.

\footnotetext{
55 optic-blowing: Cottam - Price 1998, 13; in Vorform geblasen, optisch geblasen: Rütti 1991, 26; soufflage optique: CARON - ZoÏTOPOÚlOU LIC PHIL 2008, XXXV.

56 decoration formed when the vessel was hot: CоTTAM - PRICE 1998, 30.

57 applied trail: CotTAM - Price 1998, 30-32; thread: CARON - ZoḮtopoúlou Lic PhiL 2008, XXIV; applying trails or threads: LAZAR 2003, 60; filet: CARON - Zö̈TOPoúlou Lic Phil 2008, XXXV; filamenti: Bonomi 1996, 239.

58 applied blob: Cottam - Price 1998, 30-32; blob: CAron - ZoÏtopoúlou Lic Phil 2008, XXIII; applying chips of glass, blob: LAZAR 2003, 58; décor de cabochon: Dilly - MAHÈo 1997, 14; gocce, spruzzo: Bonomi 1996, 239.
} 


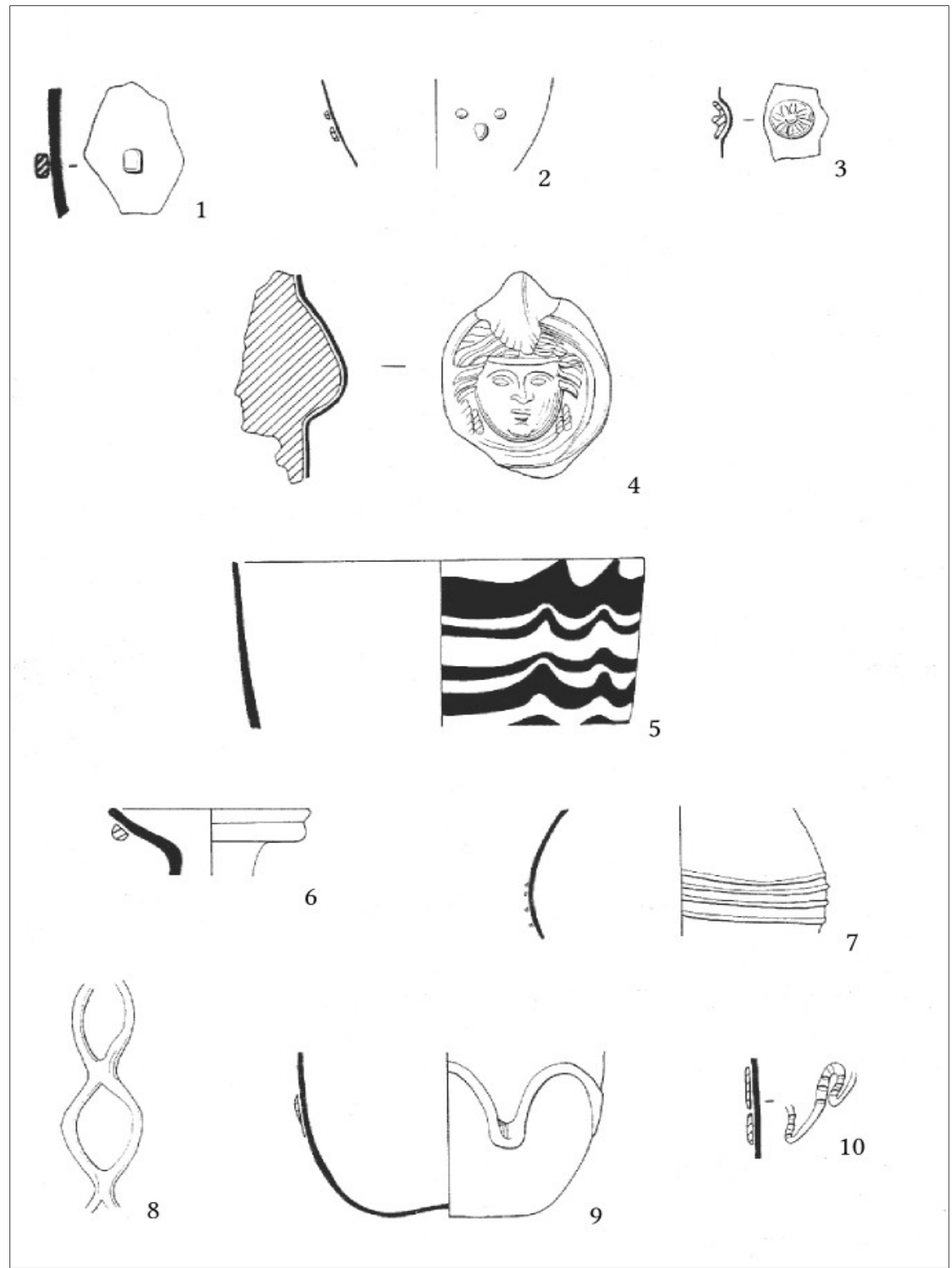

Fig. 7. Az üvegek forró díszítési módjai - Decorations formed when the vessel was hot. (COTTAM - PrICE 1998, 31). 
medalion: Főként korsók fülének attache kialakításánál jellemző használata. Előre gyártott figurális díszítésű medalionokat erősítettek a fül alsó részére, gyakran Medusa fővel, istenalakokkal, vagy oroszlánfejjel díszítettek, préselt technikával készültek (Fig. 7.4). ${ }^{59}$

az edény testéből kialakított díszités: Az edény anyagának alakítása révén létrehozott dekoráció. A 3. századi színtelen kupák, tálak, flaskák és poharak jellegzetes díszítőelemei. Így készültek különböző kiemelkedések és bütykök, függőlegesen, vagy átlósan húzódó bordázott díszek (Fig. 5.3). Ezek a 2-3. századi kannáknál együttesen is jelentkezhetnek. Szintén erre az időszakra jellemző az edény testéből kialakított csőszerű, övként körbefutó díszítés. Ekkor a mester az edény falára nyomást gyakorolva egy nyolcas alakú domborulatot hoz létre, a perem alatt vagy az edény hasán. Az edények falának ovális bemélyítéseit egy fogó segítségével, illetve gyűrűszerűen elhelyezett függőleges botocskákkal képezték ki. ${ }^{60}$

márványozott díszítés: Az edény testére felvitt pettyszerű, vagy szálként végigfutó díszítések. Miután az edény testére helyezték a forró üvegszálakat, pettyeket, cseppeket az ún. görgetőlapon való forgatás által az üveg alapanyagával teljesen összeolvadva a márványhoz hasonló mintázatú dekorációt eredményeztek (Fig. 7.5). ${ }^{61}$
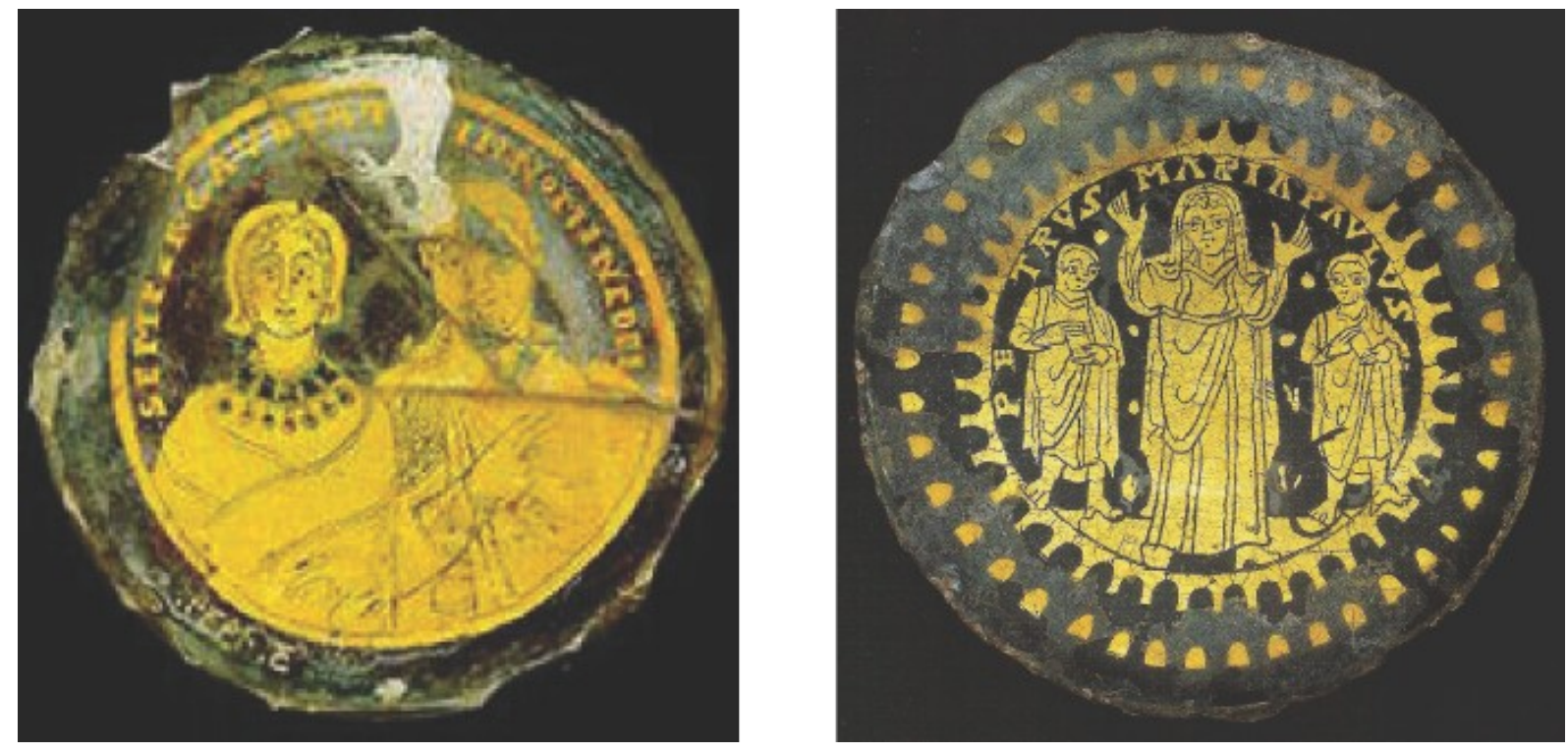

Fig. 8. Fondo d'oro üveg Lugióból (www.mult-kor.hu/attachments/17 469/dunaszek3.jpg) és a Wolf-gyüjteményből (STERN 2001, 171) - Fondo d'oro vessels from Lugio and from the collection of E. Wolf.

fondo d'oro technika: a technikával két üvegréteg közé elhelyezett aranyfóliás edényeket lehet létrehozni. Feltalálását a hellénizmus korszakához köthetjük. Ebből a korszakból a leghíresebb ilyen üvegtárgyak az ún. Canosa-tálak, ${ }^{62}$ amelyek öntéssel készültek, majd a gondosan összecsiszolt edények közé helyezték el az aranyfólia díszítést, végül újrahevítették a tárgyat. ${ }^{63}$ A római periódusban különösképp a késői, 3-4. századi már fújt technikával gyártott fondo d’oro üvegek érdemelnek említést, amelyeknek általában csupán az aljuk díszített. Az ábrázolás keresztény, illetve zsidó motívumokkal díszített, de gyakran ábrázolnak egyéni portrékat, házaspárokat, illetve

59 applied disc of glass: CоTtAm - Price 1998, 30-32; applied medallion: LAZAR 2003, 58; applique: Bonomi 1996, 239.

60 tooling, folds and indents: СотTAM - Price 1998, 30-32; nervature, bugne, depressioni: Bonomi 1996, 240.

61 marvered flush: CotTAM - Price 1998, 30-32; décor marbré: Dilly - MAhÈo 1997, 14; vetro marmorizzato: Toniolo 2000, 188.

62 Goldstein 1989, 115.

63 Goldstein 1989, 116-118. 
szülőket gyermekükkel (Fig. 8). ${ }^{64} \mathrm{Az}$ individuális ábrázolások mellett sokszor keresztény jókívánságokat olvashatunk a töredékeken. Az ilyen üvegek letört aljait gyakran megtalálhatjuk keresztény katakombákban a sír falába illesztve. ${ }^{65}$

\section{Hideg díszítési eljárások}

Ebbe a kategóriába sorolható minden olyan díszítésmód, amelyet az edény elkészítése után, annak kihűlt állapotában alkalmaztak. Ide tartozik a festés, amelynek két fajtája van. Ezen felül a különböző vésett díszítések sorolandóak a csoportba. ${ }^{66}$

„hideg festés”: Ekkor vízfestékkel, temperával, vagy olajfestékkel díszítik az edény felületét (Fig. 9). ${ }^{67}$ zománcozás: A festés másik módja amikor a festék porrá zúzott üveget tartalmaz, amit az edény felszínére olvasztanak újra felhevítés során. ${ }^{68}$
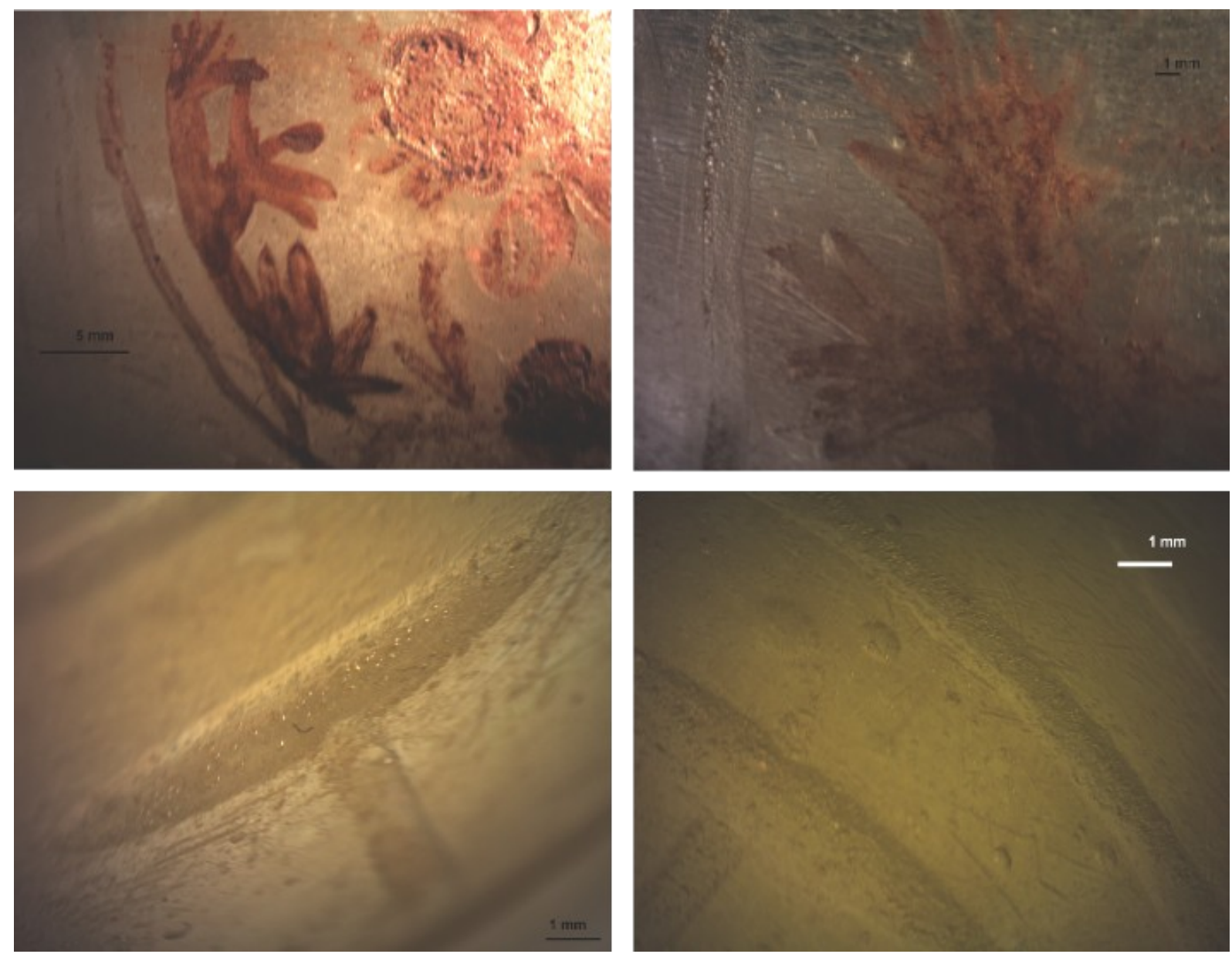

Fig. 9. Elővésett, festett díszítés palackon (fent) és vésőkerékkel készített díszítés, ún. elválasztó pálcatagok, facettált tálakon (lent) - Wheel-cutting and painting decoration of a bottle (above) and wheel-cutting, vertical lines and facet-cutting decoration (below).

kerékvésett díszités: A vésett díszek kialakításához kis fémkereket, köszörüt és egyéb vésőeszközöket használtak (Fig. 10.1). Főként színtelen üvegeken alkalmazták a technikát, az 1. század többszínü

64 STERN 2001, 139.

65 STERN 2001, 139.

66 decoration formed when the vessel was cold: COTTAM - PRICE 1998, 33-37.

67 painting: LAZAR 2003, 60; LAZAR 2004, 156-160; pittura: BONOMI 1996, 240.

68 enamel: LAZAR 2003, 60; LAZAR 2004, 156-160; enamel: PAYNTER - DUNGWORTH 2011, 31. 
tálainak és a 4. század zöldes árnyalatú edényeinek kivételével. A legegyszerübb vésett díszítést a vésőkerékkel létrehozott vízszintesen futó becsiszolt vonalak jelentik. Gyakran kombinálták egyéb, kidolgozottabb eljárásokkal. A 4. századtól kezdve vízszintesen körbefutó becsiszolt sávok díszítik az üvegzöld, zöldesbarna poharakat, tálakat és kupákat (Fig. 11.1-4). ${ }^{69}$ A Pannoniában a 2. század végén, 3. század első felében oly jellemző Isings 96 tálformákon is megfigyelhető a kerékvésett díszítés. A több sorban elhelyezett facettált oválisokat elválasztó egyes, vagy kettős pálcatagok kialakításánál használták a vésőkereket (Fig. 9). ${ }^{70}$

facettált díszítés: Tulajdonképp kör, vagy ovális alakú bevésést illetve ezek sorozatát jelenti (Fig. 10.2-7). Jellemző a 2-3. századi öntött, illetve az 1-4. századi fújt üvegekre. A fújt változat gyakori és rendkívül jó minőséget jelez. A méhsejtszerü facettált díszítés általában sorokba szedett és hálót alkot, néha bevésett vonalakkal együtt jelentkezik. A 2-3. században megjelennek az ovális és rizsszem alakú vésetek, majd a 3. századra jellemző az eddigi formák kombinálása, ezen felül a rombuszok, koszorúk, koncentrikus körök kialakítása. ${ }^{71}$

bekarcolt vonaldísz: Főként a késő római időszakra jellemző díszítésmód, amelyet leginkább pohárformákon alkalmaztak, kisebb mértékben palackokon és korsókon jelenik meg. Az edény peremén és többnyire az edény testén egy vagy több vízszintes sávban végigfutó egymás alatti, vékonyan bekarcolt vonalból áll (Fig. 11.5-8). A vonalak vastagsága általában $1 \mathrm{~mm}$ körüli és a közöttük lévő távolság is ugyanennyi. Gyakran csak megfelelő fény viszonyok között látható, sok anyagközlő publikációban meg sem említik a létét. Világosan megkülönböztethető a vastag, vésett szalagoktól, habár gyakran jelenik meg velük kombináltan, illetve pettyes rátétdísz kiegészítéseképpen. A vonalak sekélysége miatt a profil ábrázolásánál nem jeleztem. ${ }^{72}$

figurális vésett díszités: Az asztali edények jellegzetes díszítőeleme, amelyet kerékvésett és bekarcolt vonaldíszítéssel kombinálhattak. Különösen jellemző a 4. században, főként poharak és tálak díszítőelemeként, sokszor az edény csaknem teljes felületét beborító figurális díszítés alkalmazása (Fig. 5.2, Fig. 10.8-10). A legtöbb esetben kézi vésővel alakították ki. ${ }^{73}$

cameo díszítéstechnika: Az alapformát két vagy több réteg üvegből alakították ki, általában kontrasztos színek felhasználásával, a rétegek más-más színűek voltak. Gyakran a belső réteg áttetsző kék, míg a külső matt fehér volt. Ezeknek a többrétegű üvegedényeknek a for mái változatosak, lehettek csészék, palackok, amphorák és illatszeres üvegcsék. Azonban viszonylag kevés ilyen üveget ismerünk, az elkészítésük roppant nagy szakmai tudást igényelt. Gyártási technológiájuk körül sok vita folyt. A belső üvegrétegen, amely mintegy háttérként szolgált, a külső rétegből domborműszerű jeleneteket alakítottak ki, nagy valószínűséggel a külső réteg felesleges anyagának véséssel való eltávolításával. A többrétegű alapüveg elkészítése történhetett formába öntéssel, illetve fújással. A leghíresebb ezzel az eljárással készült üvegedény a Portland-váza (Fig. 12).

69 horizontal linear wheel-cutting: СоттAм - Price 1998, 33-37; wheel-cutting: LAZAR 2003, 60; lathe-cut: CARON - ZoÏToPoúlou Lic Phil 2008, XXIII; schneiden, gravieren: SieBel 2008, 176; intaglio: Bonomi 1996, 240.

70 BARKóczi 1986, 169-188.

71 facett-cutting: CotTAM - Price 1998, 33-37; facett-cutting: LAZAR 2003, 61; décor facette taillée: Dilly - MAHÈo 1997, 16; facettált díszítés: PÁNCZÉL - LÁzoK 2005, 172.

72 abraison: CотtAM - Price 1998, 34; abrasion bands: JenIngs 2004-2005, 305; Punktlinien: RÜTti 1991, 212; feine eingeschliffenen Linien: Pirling 1979, 115-131; ligne tracée: Dilly - MAhÈo 1997, 14; incisione: Bonomi 1996, 240.

73 figured-cutting: СоTTAM - Price 1998, 36; figured-cutting: LAZAR 2003, 60. 


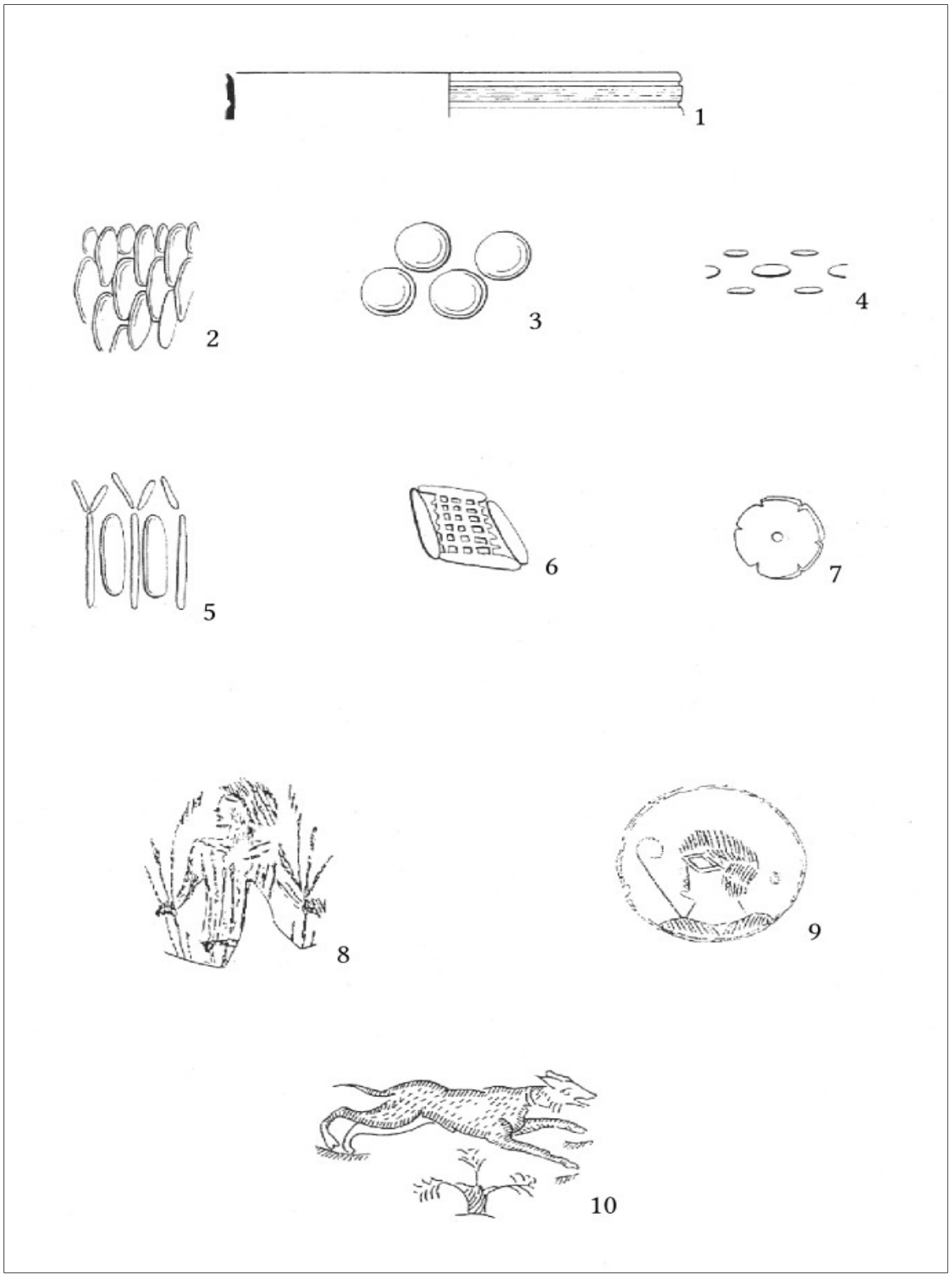

Fig. 10. Az üvegek hideg díszítési eljárásai - Decorations formed when the vessel was cold. (COTTAM - PRICE 1998, 35). 


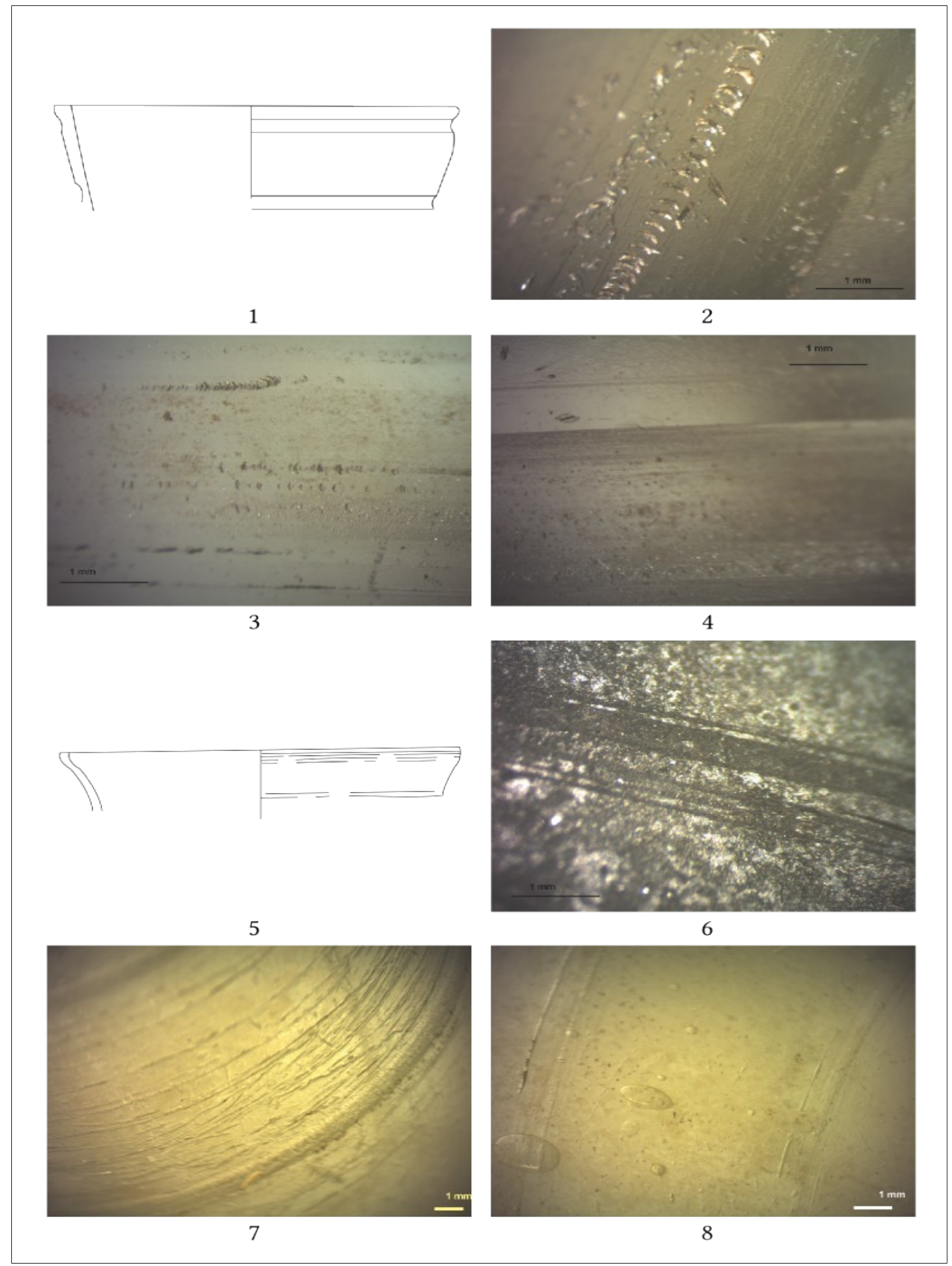

Fig. 11. 1. Kerékvésett díszítés - Wheel-cutting decoration. 2. Vésőkerék megcsúszásának mikroszkopikus nyoma Chattermark of wheel-cut. 3-4. Vésőkerék mikorszkopikus nyomai - Microtraces of wheel-cutting. 5. Bekarcolt vonaldíszítés - Abrasion bands. 6. Bekarcolt vonaldíszítés mikroszkopikus nyoma - Microtrace of abrasion bands. 7. Bekarcolt és kerékvésett díszítés együttes alkalmazása - Wheel-cutting line and abrasion bands. 8. Bekarcolt vonaldíszítés mikroszkopikus nyoma - Microtrace of abrasion bands. 
diatreta üveg: Ezen tulajdonképp egyfajta hálódíszítést értünk (Fig. 12). A. 4. században jelentek meg ezek a vésőkerékkel díszített üvegek. A legritkább, legdrágább késő római üvegfajtának tekinthetjük. A hálódíszes üvegeknél a díszítés általában ugyanabból az anyagból készült, mint az alapüveg. A dísz tojás alakú, vagy kerekded gyürükből áll, amelyeket az üvegtestre merőleges kis csapok tartanak. Gyakori a perem alatti felirat megjelenése, amelyet ugyancsak csapok rögzítenek, amelyek sok esetben keresztény jellegüek. Valószínűleg a vas diatretumok áttört díszeinek előképei olyan üvegedények lehettek, amelyeknek nemesfém anyagú, áttört díszítésű foglalata volt. A sokáig „Nero pohara” néven emlegetett edénytípus készítéstechnikáját elsőként J. J. Winckelmann elemezte, kiemelve a vésett díszítés alkalmazását, neki köszönhetjük a vasa diatreta elnevezést is. ${ }^{74}$
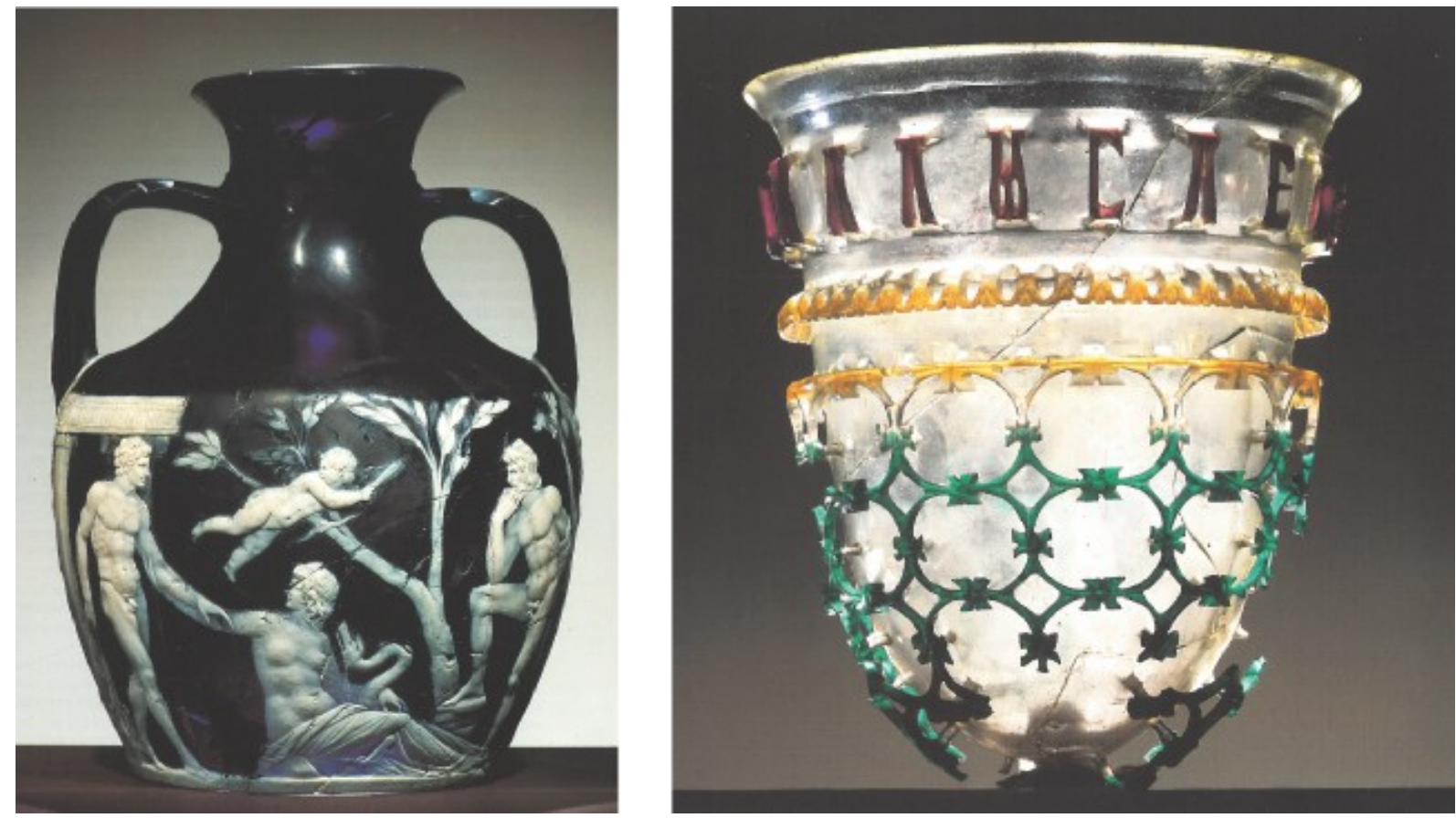

Fig. 12. A Portland-váza (HARden 1988, 58) és egy vas diatretum Köln-Braunsfeldből (Harden 1988, 240) - The Portland Vase and a diatreta cup from Köln-Braunsfeld.

\section{Az üvegek színe}

színes üveg: Élénk színű üveget kapunk, ha az üveg alapanyagaihoz színező segédanyagokat teszünk. Néhány már az alapanyagokban megtalálható (vas, szén), míg másokat tudatosan adnak a nyersanyaghoz. Alapjában háromféle eljárás adott a színezésre. A színezőanyag az alapüvegben feloldódik, az alapüvegben apró szemcsékben kiválik, de festék alakjában is felvihető (lásd: díszítés). Réz hozzáadásával nyerhetünk vörös, zöld és kék színt, mangán adalékkal bíbor, barna és fekete tónust kapunk, míg a kobalt kék árnyalatot eredményez. Az ólom, vagy antimon sárgás színt ad. Élénk színű fújt üvegek, mint például az opak, vagy áttetsző kék, zöld, barna, sárga, piros és lila színű, gyakran ellenkező tónusú pettyekkel és sávokkal díszített edények a római korban az 1. század termékei, később veszítenek népszerűségükből. Az üvegfújás feltalálása előtt pedig főként az élénk színű üvegek voltak jellemzőek, és mind a monokróm, mind a polikróm edényeknél meghatározóak. ${ }^{75}$

75 strong colours: COTTAM - PRICE 1998, 15; colured glass: LAZAR 2003, 23. 
színtelen üveg: Az üveggyártás céljaira felhasznált nyersanyagok többé-kevésbé szennyező anyagokat tartalmaznak. Különösen jelentős ilyen szempontból a homok vasoxid tartalma, amely az üvegnek zöldes színt kölcsönöz, ennek ellensúlyozására a római korban főként a fizikai színtelenítést alkalmazták, ami azt jelenti, hogy a vasoxid által létrehozott zöldes színt egy megfelelően kiválasztott adalékkal kiegészítik. A zöldes színnek a rózsa a kiegészítője. Nem túl magas vasoxid tartalom mellett az összeolvadó színek színtelen üveget eredményeznek. Ilyen anyag a már az ókorban is használt antimon, vagy a mangán-dioxid. Az élénk színű asztali edények gyártása gyorsan visszaesett, amikor a színtelen üveg megjelent az 1. század közepén. Ezután egyre inkább a színtelen üveget részesítették előnyben az asztali edények készítésénél és egészen a késő római időkig népszerű maradt az asztali használatra szánt edényeknél éppúgy, mint az illatszeres üvegeknél. ${ }^{76}$

üvegzöld: Az üveg alapanyagában jelenlévő szennyező anyagoknak köszönhető jellegzetes zöldes színárnyalat, amelyet fóként a homok vasoxid tartalma okoz. Abban az esetben beszélhetünk üvegzöld edényről, ha az alapanyag olvasztása során sem színező, sem pedig színtelenítő segédanyagokat nem adnak az üveghez. Jellemzően a tároló-szállító feladatok betöltésére szánt üvegek tónusa a római korban. Másik elnevezése a palackzöld szín. ${ }^{77}$

\section{Az üveg átlátszósága}

átlátszó üveg: Az üvegek átlátszósága attól függ, hogy az üvegre eső fény milyen mértékben jut át rajta, nyelődik el benne, avagy verődik vissza róla. Az átlátszó üvegre jellemző, hogy a rá eső fény közel 100 százaléka átjut az üvegen. ${ }^{78}$

áttetsző üveg: Az üvegre eső fénynek ebben az esetben csak egy része jut át, a másik része elnyelődik benne. Általában a beeső fehér fénynek nem a teljes spektruma hatol át rajta, így az átjutó fény színesnek látszik. ${ }^{79}$

opak üveg: Tulajdonképpen átlátszatlan üveg, az üvegre eső fényből semmi sem jut át, de jellemző, hogy szóródva visszaverődik. Ha ez a szóródás teljes az üveg tejfehér, ha részleges, akkor különböző színű, ha az összes fény elnyelődik, akkor pedig fekete. Ezeket az üvegeket homályosított, vagy mattosított üvegeknek is nevezzük, mivel az átlátszatlanságot ún. homályosító anyagokkal tudatosan hozzák létre. ${ }^{80}$

\section{Az üvegedények részei}

\section{Perem}

melegen lekerekitett perem: Az edény készítésénél a szájrész kialakítása végett az üveget tartórúdra helyezték át és a peremnél a felesleges üveget lerepesztés által eltávolították, majd a tartórúdra helyezett edény peremrészét újra felhevítették, ami ezáltal tökéletesen lekerekítetté vált (Fig. 13.1, Fig. 13.4). Ez a fajtája a peremkialakításnak 1-4. században elterjedt, de különösen nagy népszerűségnek a 2. század közepétől a 3. század közepéig örvendett. ${ }^{81}$

76 colourless glass: COTTAM - PRICE 1998, 15-16; farblos: Rütti 1991, 109; colourless or decoloured glass: LAzAR 2003, 24.

77 Naturfarbe: RÜTTI 1991,110; Flaschengrün: PIRLING 1979, 115-131; Glasgrün: BERGER 1960; blue-green or naturally coloured glass: LAZAR 2003, 24.

78 transparent, transparente: TONIOLO 2000, 194; átlátszó: FóRIZs ET AL. 2000, 321.

79 translucent, translucido: ToNiolo 2000, 194; áttetsző: FóRIzS ET AL. 2000, 321.

80 opacifiers, opacizzanti: Bonomi 1996, 2345; opaque, opaco: Toniolo 2000, 194; opak: FóRIzs et al. 2000, 321.

81 fire rounding rim: CotTAM - Price 1998, 22-23; fire rounding rim: LAZAR 2003, 19; mit gerundetem Rand: RüTTI 1991, 100; rundgeschmolzener Rand: PIRLING 1966, 115-131. 


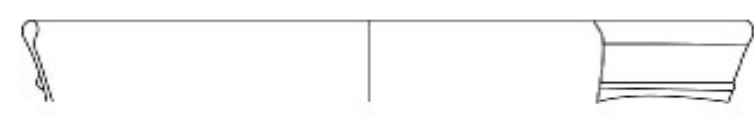

1

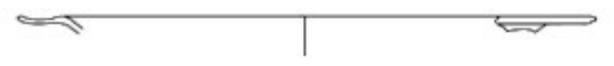

3

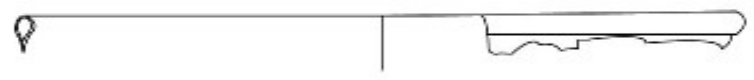

5
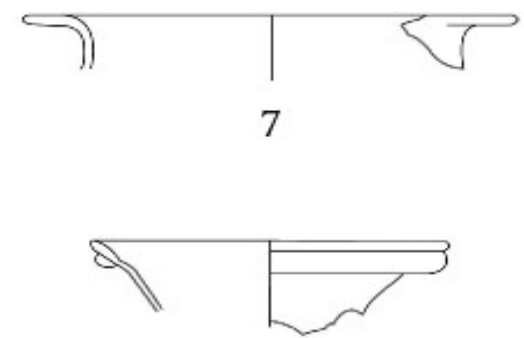

9

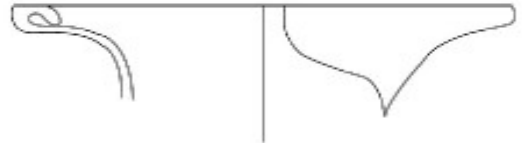

11

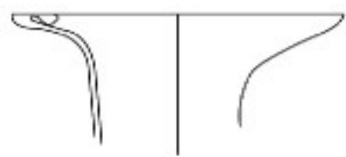

13

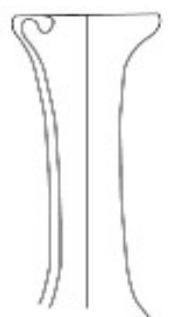

15

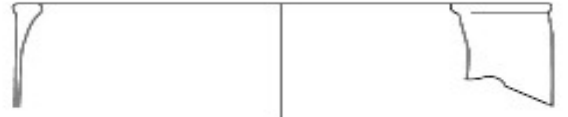

2

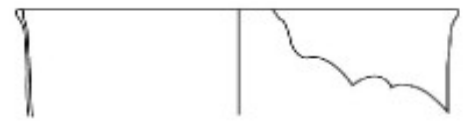

4

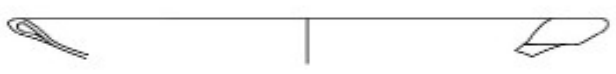

6

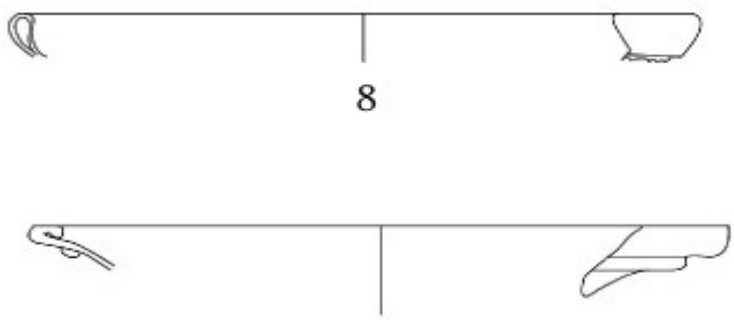

10

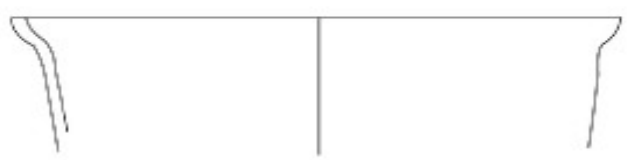

12

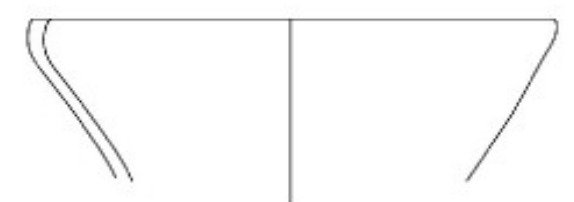

14

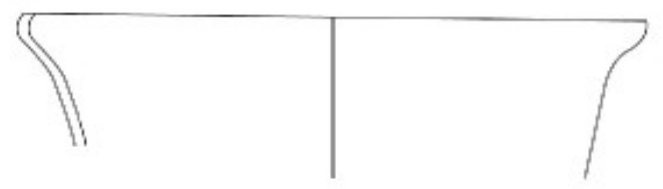

16

Fig. 13. 1-2, 4. Melegen lekerekített perem - Fire rounding rim. 3, 7. Melegen lekerekített, vízszintesen kihajló perem - Horizontally fire rounding rim. 5-6, 8. Melegen lekerekített, kifelé visszahajtott perem - Tubular outturning rim. 9. Melegen lekerekített perem, alatta szálrátét gyűrűvel - Fire rounding rim and applied trail. 10. Melegen lekerekített, befelé visszahajtott perem, szálrátét gyűrűvel - Rolled-in rim and applied trail. 11, 13, 15. Melegen lekerekített, befelé visszahajtott perem - Rolled-in rim. 12, 16. Ívelt, vágott perem - Curved, crackedoff rim. 14. Vágott perem - Cracked-off rim. 
melegen lekerekített, megvastagodó perem: Kialakítása lényegében megegyezik az előzővel, a különbség csupán annyi, hogy addig hevítik a peremrészt, ameddig nemcsak lekerekednek az élek, hanem enyhén meg is vastagszanak (Fig. 13.2, Fig. 13. 9). Főként az 1. század végén és a 2 . században volt kedvelt peremkialakítási módszer. ${ }^{82}$

melegen lekerekitett, befelé visszahajtott perem: A melegen lekerekített peremrészt az újrahevítés során megnyújtották, majd befelé visszahajtották, így csőszerű peremet kaptak. Végül az így kiképzett peremrészt kissé ellapították (Fig. 13.10-11, 13, 15). Gyakran alkalmazták az illatszeres üvegcséknél, palackoknál, korsóknál, segítségével megelőzhető volt a folyadék lecseppenése az italfelszolgáló edények esetében. ${ }^{83}$

melegen lekerekített, kifelé hajtott perem: Miután a peremet újrahevítették, a peremrészt kissé megnyújtották, kifelé hajtották vissza az edény falának külső részéig (Fig. 13.5-6, 8). Ennél az eljárásnál is kis csőszerű peremet nyertek. Ritkábban alkalmazott eljárás mint a befelé visszahajtott peremkiképzés. Főként az 1-2. század kedvelt eljárása, elsősorban a tálaknál és a fazékformáknál figyelhetjük meg az alkalmazását. ${ }^{84}$

melegen lekerekített galléros perem: A peremrész újrahevítése után megnyújtották, majd kifelé és lefelé húzták hosszabban, mint a kifelé hajtott peremnél. Ezután hozzányomták az edény falához, így nem keletkezett csőszerű, kerek átmetszetű rész, mint a kifelé hajtott peremnél. Főként urna és fazékformáknál volt használatos az $1-2$. században. ${ }^{85}$

melegen lekerekitett, kifelé ívelt perem: A melegen lekerekített perem kifelé dőlő változata (Fig. 13.3). ${ }^{86}$

vágott perem: Az edény készre fúvása után a fújócsőhöz közeli részének levágása által keletkező, jellegzetesen éles szélekkel rendelkező peremkialakítás. A már kihült üvegedényre a perem feletti részen forró üvegszálat, vagy ha az edény még meleg volt hideg vizet csorgattak, ezáltal a keletkező felületi feszültség következtében a felső rész lerepedt (Fig. 13.12, 14, 16). Valószínúleg a második mód lehetett elterjedtebb. Az ezzel az eljárással készült peremek vastagsága megegyezik az edény falvastagságával, egyáltalán nem vastagodik meg. Az így nyert perem éles, durva felszínü, ezt utólagosan csiszolással tehették finomabbá (Fig. 14). A 4-5. századi üvegeknél jellegzetes megoldás, hogy a peremrészt durva felszínűre hagyják, nem csiszolják le a jellegzetes éleket. Az egyrészes, formába fújt, nyitott edényformák befejezése túlnyomó többségében ezzel az eljárással történt. ${ }^{87}$

\section{Fül}

bordázott szalagfül: Az edény testének kiképzése után még forró állapotban, változatos formában ragasztottak az edényre fület, forró üvegszálból a nyak és vállrészre, valamint a peremre. Gyakran applikálták a vállra, vagy az edény testének felső részére és felhúzták, majd hozzá csatolták a perem éléhez, vagy ez alá. Sok variáció lehetséges formában és díszítésben. A bordázott fül esetében, miután felragasztották egy fésűszerű eszközzel a külső felületén egymással párhuzamosan futó függőleges bordasort alakítottak ki (Fig. 16.15-16). ${ }^{88}$

82 fire-thickened rim: LAZAR 2003, 19.

83 rolled-in rim: СоTTAM - PRICE 1998, 22-23; mit gebogenem gerundetem Rand: RÜTTI 1991, 101; flattend rim: LAZAR $2003,20$.

84 tubular rim: COTTAM - PRICE 1998, 22-23; tubular rim: LAZAR 2003, 19.

85 collar rim: LAZAR 2003, 20.

86 mit aussen gewölbtem Rand: RÜTTI 1991, 66.

87 cracked-off rim: COTTAM - PRICE 1998, 24; mit absprengtem Rand: RÜtTi 1991, 46; absprenger Rand: PiRLING 1966, 115-131; cut rim: LAZAR 2003, 20; absprengen: SIEBEL 2008, 176.

88 ribbon handle with fine vertical ribs: СоTTAM - Price 1998, 25; ribbed handle, reeded handle: LAZAR 2003, 22. 


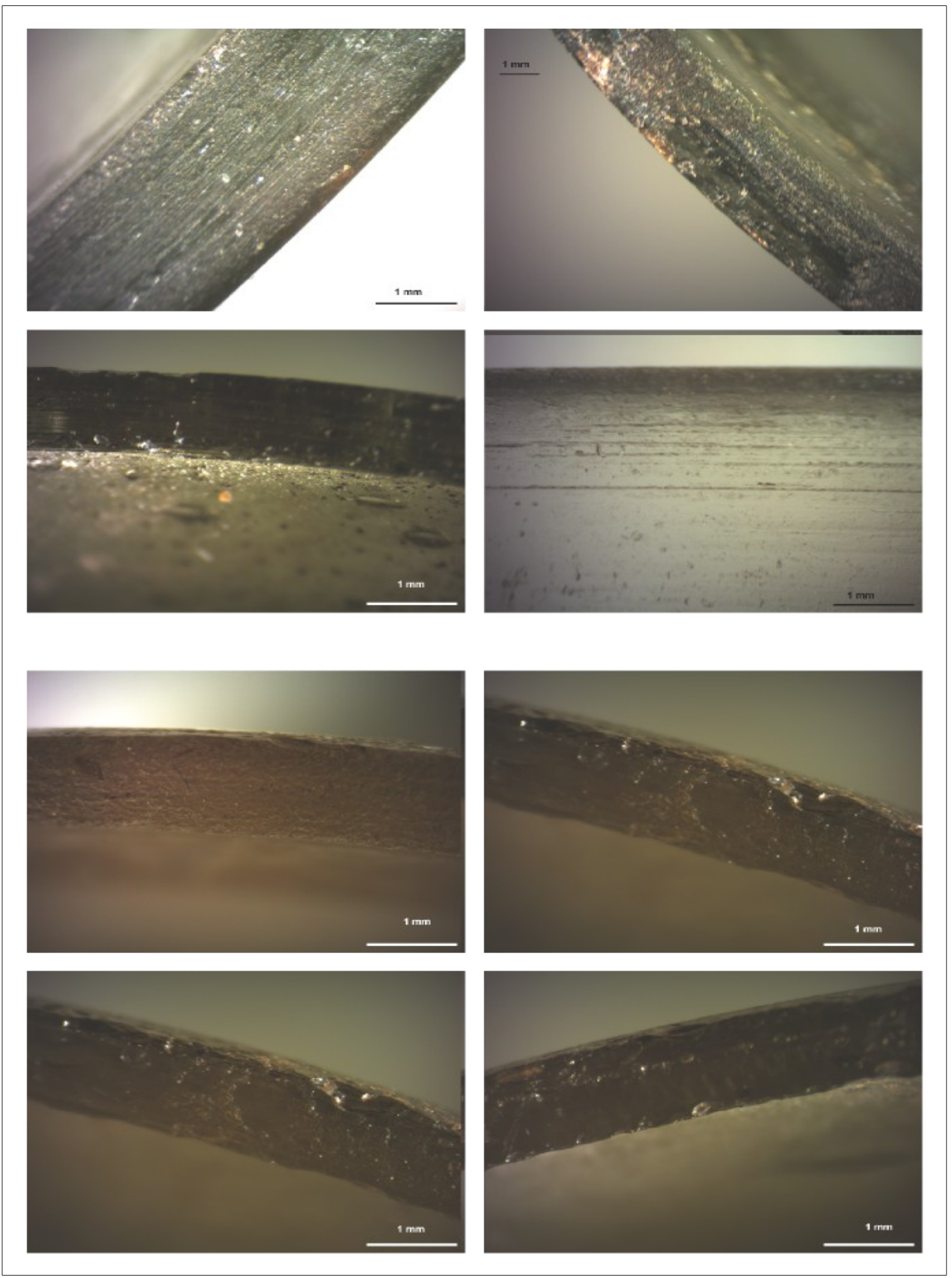

Fig. 14. Vágott, csiszolt (felül) és csiszolatlan perem (alul) - Cracked-off, polished (above) and unpolished rim (below). 
sima felületü szalagfül: A fent említett módon, változatos formában létrehozott fül, amelynek külső felületén nem alkalmaztak díszítést, így felülete teljesen sima maradt. Az üvegszálat optikai formába helyezhették a nyújtás és applikálás előtt, ebben az esetben a szalagfül úgy tünik, mintha több sávból állna. ${ }^{89}$

profilált szalagfül: Lényegében megegyezik a sima szalagfüllel, azonban olyan módon alakították ki, hogy a fül szélei megvastagszanak (Fig. 16.17-18). ${ }^{90}$ Gyakran a peremrész fölé ívelő kis hurok segítségével ujjtámasztó részt alakítottak ki a fülből (Fig. 15).

rúd alakú fül: Kör, háromszög vagy D átmetszetű vastag, markáns fülkiképzés, amelyet előre gyártott üvegrudak újrahevítésével, majd az edényhez való csatlakoztatásával nyertek. ${ }^{91}$

láncszem alakú fül: Láncszemeket mintázó fülkiképzés, amelyet két vagy több üvegszál felhasználásával hoztak létre. Végeit kissé egymásra nyomva alakították ki a lánc kötéseit. Használata elsősorban a kölni korsókra jellemző. ${ }^{92}$

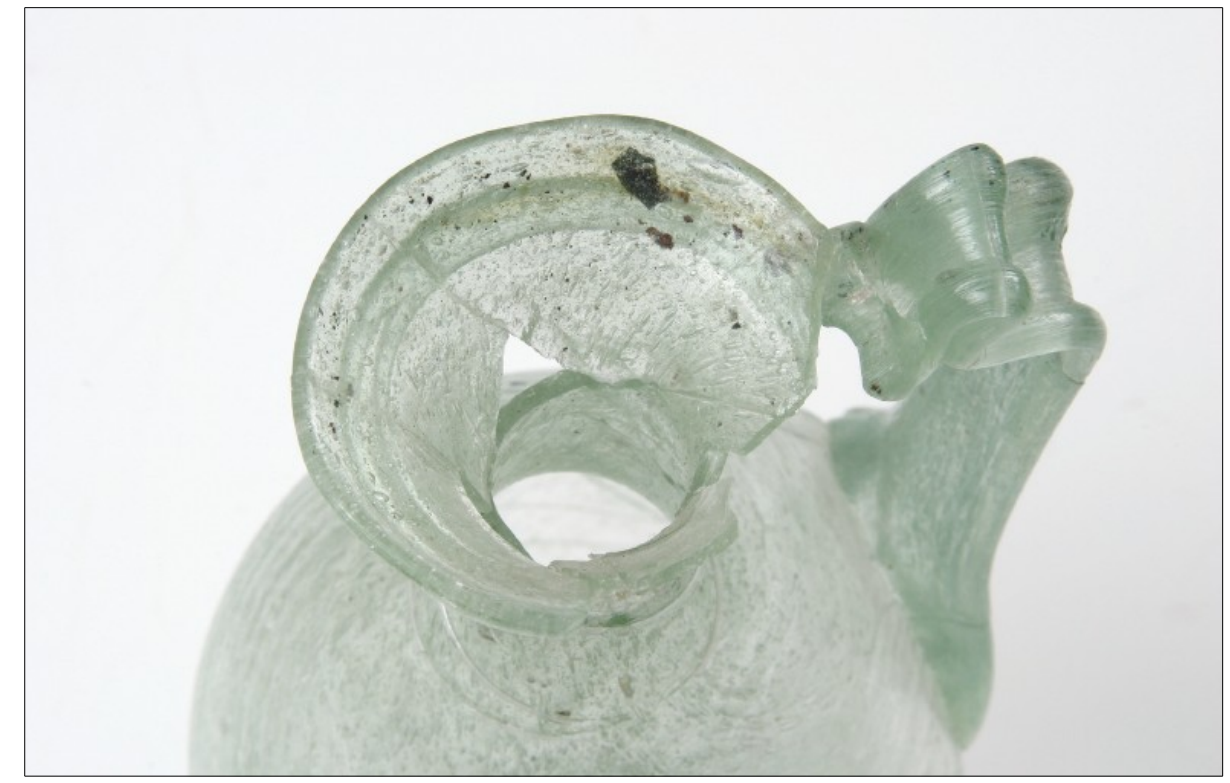

Fig. 15. Ujjtartó rész kialakítása szalagfüllel ellátott korsón Ribbon handle of a jug with a finger rest (Photo: Tímárné Sinkó A.)

\section{$\boldsymbol{A l j}$}

talpgyürüs alj: Több változata ismert, az egyik leggyakoribb aljtípus. Lehet az edény testéből kialakított, tömör, vagy csőszerű alj. Ezenkívül a leggyakoribb a külön plasztikus szálrátét gyürűből, vagy gyűrűkből kialakított talprész, amelyet még forró állapotban helyeztek az edényre (Fig. 16.8-10). ${ }^{93}$

egyenes alj: Az edény elkészítése után egyszerủen ellapították az edény alját, hogy az vízszintes felületen meg tudjon állni (Fig. 16.1-3). ${ }^{94}$

89 ribbon handle: COTTAM - PRICE 1998, 25; banded handle: LAzAR 2003, 22.

90 profiled handle: LAZAR 2003, 22.

91 rod handle: COTTAM - PRICE 1998, 25; triangular handle: LAZAR 2003, 22.

92 chain handle: COTTAM - PRICE 1998, 25

93 open or closed base ring: COTTAM - PRICE 1998, 25-29; Fadenstandring, mit einem durch Faltung gebildeten Standring: RÜTTI 1991, 77; base with a base ring, base with a tubular base ring, base with a double base ring: LAZAR 2003, 21.

94 flat base: LAZAR 2003, 21. 


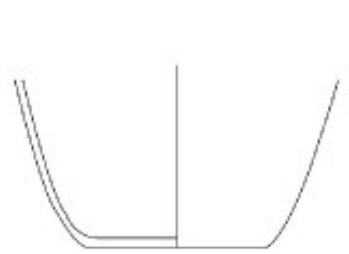

1

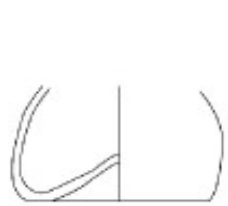

4

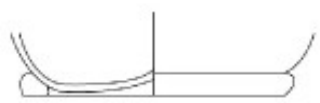

8

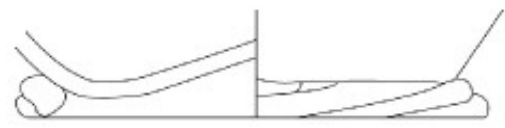

10

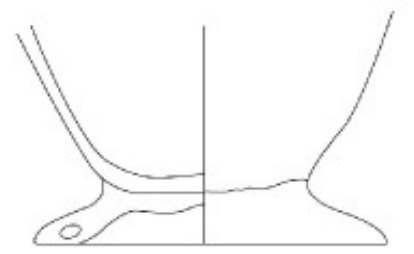

13

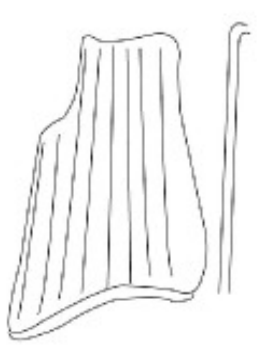

15

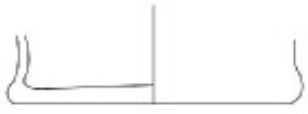

2

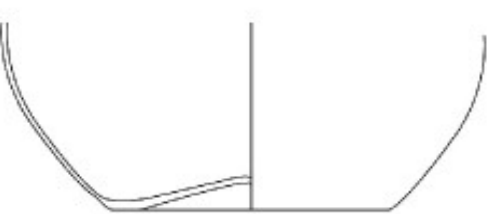

5
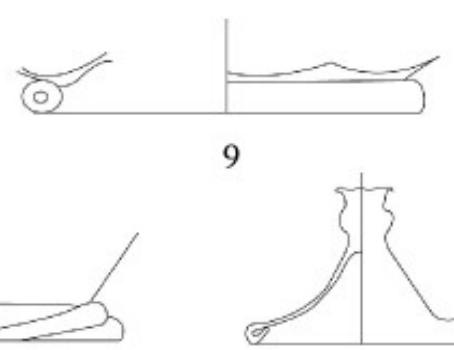

9

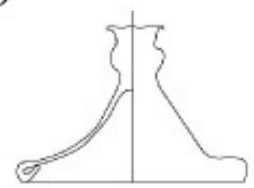

11

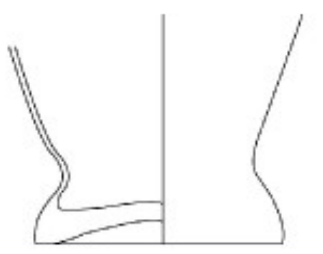

3

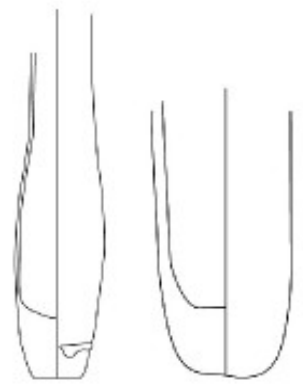

6

7

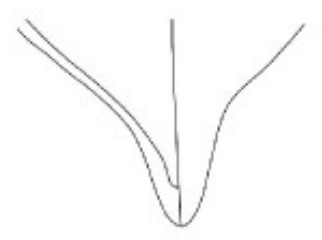

12

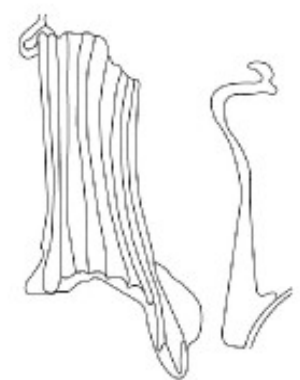

16

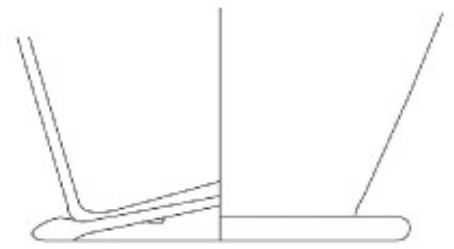

14
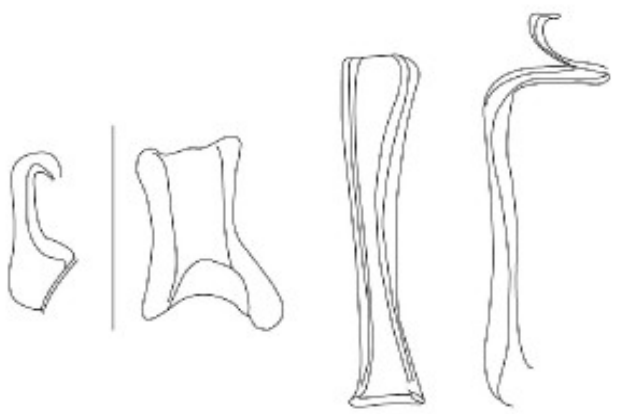

18

Fig. 16. 1-2. Egyenes alj - Flat base. 3. Egyenes, megvastagodó, enyhén benyomott alj - Concave base. 4-5. Egyenes, benyomott alj - Concave base. 6-7. Megvastagodó, lekerekített alj - Rounded base. 8. Szálrátét talpgyưrü - Base ring from a spiral trail. 9. Csőszerű, szálrátét talpgyűrü - Tubular base ring. 10. Több szálból csavart talpgyürü - Base ring from spiral trails. 11. Külön bogból készített talpgyürü - Separately blown foot. 12. Gombban végződő alj - Base knob. 13-14. Külön bogból készített talpgyürűk - Separately blown base. 15-16. Bordázott szalagfül - Ribbon handle with fine vertical ribs. 17-18. Profilált szalagfül - Profiled handle. 
benyomott alj: Ebben az esetben nem alakítanak ki talpgyűrüt, hanem ellapítják az aljat, majd ezután a tartórúd ráhelyezésekor kisebb-nagyobb nyomást gyakorolnak rá, így az különböző mértékben benyomódik, ezáltal a külső élek nagyobb stabilitást kapnak és az edény jobban meg tud állni vízszintes felületen (Fig. 16.4-5). ${ }^{95}$

külön bogból kialakított kónikus alj: Különösen a magas, karcsú kelyheknél, kupáknál, valamint a korsóknál fordul elő, hogy az edény testének készre fújása után, egy külön kis bogból magas, kónikus formájú aljat fújnak, vagy formálnak, amelyet még forró állapotában ragasztanak az üveghez és csak ennek felhelyezése után teszik rá az edényt a tartórúdra a peremkialakítás befejezése végett (Fig. 16.13-14, Fig. 16.11). A bog a fújócsőre merített nagyobb vagy kisebb méretű kidolgozási hőfokon lévő üvegmennyiség, amely a merítés folyamán ovális vagy gömb formájú alakot vesz fel..$^{96}$

megvastagodó, tömör alj: Elsősorban öntött, illetve formába fújt edényeknél fordul elő, ahol az öntés illetve a formába fújás miatt az alj nem lesz egyenletes vastagságú, az átmérője általában a közepe felé enyhén megvastagodik. Elsősorban palackoknál, korsóknál, illatszeres edényeknél találkozunk ezzel az eljárással. Ezekben az esetekben az alj átmérője meghaladja az edény falának átmérőjét, ezért indokolt a tömör jelző használata (Fig. 16.6-7). ${ }^{97}$

gombban végződő alj: Főként amphorák, illatszeres üvegek és a késő római időszakban megjelenő lámpásként is használt kónikus, formába fújt üvegedények aljára jellemző, megvastagodó, tömör kis csúcsszerü aljkiképzés (Fig. 16.12). ${ }^{98}$

\section{Irodalom}

BARKóczi, L. 1986: A 3. sz. első feléből származó vésett díszü üvegek Pannoniában. Archaeologiai Értesitó 113, 166-189.

Berger, L. 1960: Römische Gläser aus Vindonissa. Veröffentlichungen der Gesellschaft pro Vindonissa 4, Basel.

Bonomi, S. 1996: Vetri antichi del Museo Archeologico Nazionale di Adria. Corpus delle Collezioni del vetro nel Veneto 2, Venezia.

Caron, B. - Zoïtopoúlou Lic Phil, E. 2008: Montreal Museum of Fine Arts, Collection of mediterranean Antiquities. Musée des Beaus-Arts de Montréal, La collection des antiquités méditerranéennes 1. The Ancient Glass. La verrerie antique. Leiden/Boston.

Cottam, S. - Price, J. 1998: Romano-British glass vessels: A handbook. York.

Dilly, G. - MahÉo, N. 1997: Verreries antiques du Musée de Picardie. Amiens.

Drescher, K. 1972: Üvegfújó szakmai ismeret I. Budapest.

Facchini, G. M. 1999: Vetri antichi del Museo arceologico al Teatro romano di Verona e di altre collezioni veronesi. Corpus delle Collezioni del vetro nel Veneto 5, Verona.

FIScher, A. 2009: Vorsicht Glas! Die römischen Glasmanufakturen von Kaiseraugst. Forschungen in Augst 37, Augst.

95 mit gefaltetem Fuss: RÜTTI 1991, 55; concave base: LAZAR 2003, 21.

96 separately blown foot: COTTAM - PRICE 1998, 25-29; mit konischem Fuss: RÜTTI 1991, 57; separately blown foot, separately blown high foot: LAZAR 2003, 21.

97 Standplatte: RüTTI 1991, 122.

98 base knob: HARDEn 1936, 156., type VI.d; solid knobbed stem: JenNings 2004, 146-147. 
Fórizs, I. - PÁsztor, A. - NAgy, G. - Tóth, M. 2000: Avar kori üveggyöngyök röntgendiffrakciós és elektron-mikroszondás vizsgálata. In: Bende, L. - Lőrinczy, G. - SzAlontAI, Cs. (eds.), Hadak útján. Szeged, 321-340.

Foy, D. - Nenna, M. D. 2001: Tout feu tout sable. Mille ans de verre antique dans le Midi de la France. Marseilles.

Goldstein, S. M. 1989: Old Glass, new Glass, gold Glass: some throughts on ancient casting technology. Kölner Fahrbuch für Vor- und Frühgeschichte 22, 115-120.

Harden, D. B. 1936: Roman Glass from Karanis. Found by the University of Michigan Archaeological Expedition in Egypt. 1924-29. Oxford.

Harden, D. B. 1988: Glas der Caesaren. Milano.

Jennings, S. 2004-2005: Vessel glass from Beirut. Bey 006, 007 and 045. Berytus 48-49, Beirut.

LAZAR, I. 2003: Rimsko Steklo Slovenije. The Roman Glass of Slovenia. Ljubljana.

LazAR, I. 2004: Drobci Antičnega Stekla. Fragments of ancient Glass. Koper.

PÁnczél, Sz. P. - LÁzoK, K. 2003: A római Dácia üvegművessége. In: BAJusz I. (ed.), Mindennapi élet a római Dáciában. Kolozsvár, 153-295.

Paynter, S. - Dungworth, D. 2011: Archaeological Evidence for Glassworking: Guidelines for Best Practice. English Heritage.

PIRLING, R. 1966: Das römisch-fränkische Gräberfeld von Krefeld-Gellep. Berlin.

Ravagnan, G. L. 1994: Vetri antichi del Museo Vetrario di Murano. Corpus delle Collezioni del Vetro nel Veneto 1, Murano.

RÜтTI, B. 1991: Die römischen Gläser aus Augst und Kaiseraugst. Forschungen in Augst 13, Augst.

von SAldern, A. 2004: Antikes Glas. Handbuch der Archäologie. München.

Schuler, F. 1959: Ancient Glassmaking Techniques. The Blowing Process. Archaeology 12, 116-122.

SEIBEL, F. 1998: Technologie und Fertigungstechniken römischer Glashütten. Am Beispiel der Ausgrabungen im Hambacher Forst: aktualistische Vergleiche und Modelle. Berlin.

Stern, E. M. - Schlick-Nolte, B. 1994: Frühes Glas der alten Welt. 1600 v. Chr.-50 n. Chr. Sammlung Ernesto Wolf. Stuttgart.

StERn, E. M. 2001: Römisches, byzantinisches und frühmittelalterliches Glas. 10 v. Chr.-700 n. Chr. Sammlung Ernesto Wolf. Stuttgart.

TAYlor, M. - Hill, D. 2008: Experiments in the reconstruction of a Roman Wood-Fired Glassworking Furnaces. Journal of Glass Studies 50, 249-270.

Toniolo, A. 2000: Vetri antichi del Museo Archeologico Nazionale di Este. Corpus delle Collezioni del vetro nel Veneto 6, Padova.

Zampieri, G. 1998: Vetri antichi del Museo Civico Archeologico di Padova. Corpus delle Collezioni del vetro nel Veneto 3, Padova. 